Review

\title{
The role of sex hormones and steroid receptors on female reproductive cancers
}

\author{
Luiz Gustavo de Almeida Chuffa ${ }^{\mathrm{a}, *}$, Luiz Antonio Lupi-Júnior ${ }^{\mathrm{a}}$, Aline Balandis Costa ${ }^{\mathrm{b}}$, \\ João Paulo de Arruda Amorim ${ }^{\mathrm{c}}$, Fábio Rodrigues Ferreira Seiva ${ }^{\mathrm{d}}$ \\ ${ }^{a}$ Department of Anatomy, IBB/UNESP, Institute of Biosciences of Botucatu, Univ. Estadual Paulista, SP, Brazil \\ ${ }^{b}$ Department of Nursing, UENP/CLM - Universidade Estadual do Norte do Paraná, PR, Brazil \\ ${ }^{\mathrm{C}}$ Department of Anatomy, UNIOESTE/FB - Universidade Estadual do Oeste do Paraná, PR, Brazil \\ ${ }^{\mathrm{d}}$ Department of Biology and Technology, UENP/CLM - Universidade Estadual do Norte do Paraná, PR, Brazil
}

\section{A R T I C L E I N F O}

\section{Article history:}

Received 23 September 2016

Received in revised form 10 December 2016

Accepted 24 December 2016

Available online 29 December 2016

\section{Keywords:}

Ovarian cancer

Breast cancer

Endometrial cancer

E2

P4

ER

PR

\begin{abstract}
A B S T R A C T
Sex steroids have been widely described to be associated with a number of human diseases, including hormone-dependent tumors. Several studies have been concerned about the factors regulating the availability of sex steroids and its importance in the pathophysiological aspects of the reproductive cancers in women. In premenopausal women, large fluctuations in the concentration of circulating estradiol (E2) and progesterone (P4) orchestrate many events across the menstrual cycle. After menopause, the levels of circulating E2 and P4 decline but remain at high concentration in the peripheral tissues. Notably, there is a strong relationship between circulating sex hormones and female reproductive cancers (e.g. ovarian, breast, and endometrial cancers). These hormones activate a number of specific signaling pathways after binding either to estrogen receptors (ERs), especially ER $\alpha$, ER $\alpha 36$, and ER $\beta$ or progesterone receptors (PRs). Importantly, the course of the disease will depend on particular transactivation pathway. Identifying ER- or PR-positive tumors will benefit patients in terms of proper endocrine therapy. Based on hormonal responsiveness, effective prevention methods for ovarian, breast, and endometrial cancers represent a special opportunity for women at risk of malignancies. Hormone replacement therapy (HRT) might significantly increase the risk of these cancer types, and endocrine treatments targeting ER signaling may be helpful against E2-dependent tumors. This review will present the role of sex steroids and their receptors associated with the risk of developing female reproductive cancers, with emphasis on E2 levels in pre and postmenopausal women. In addition, new therapeutic strategies for improving the survival rate outcomes in women will be addressed.
\end{abstract}

(c) 2016 Elsevier Inc. All rights reserved.

\section{Contents}

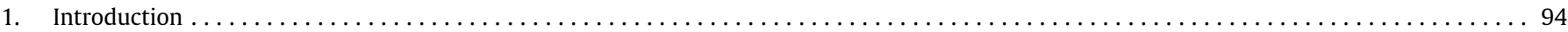

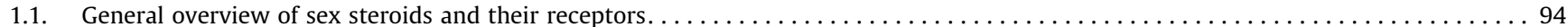

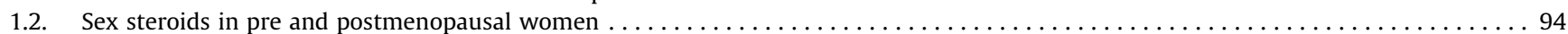

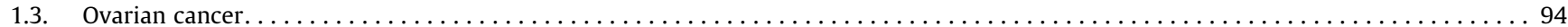

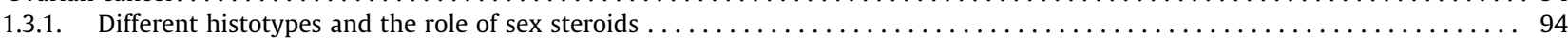

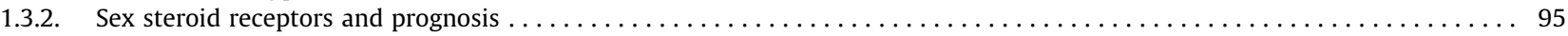

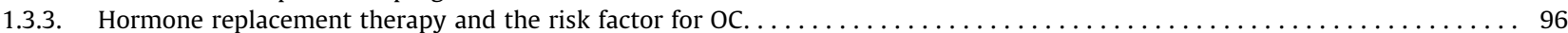

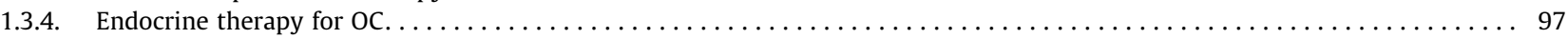

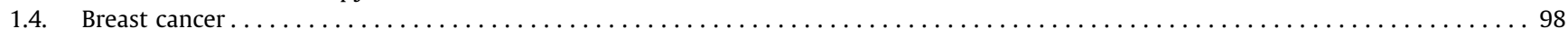

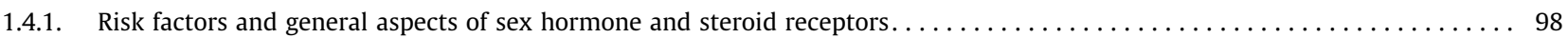

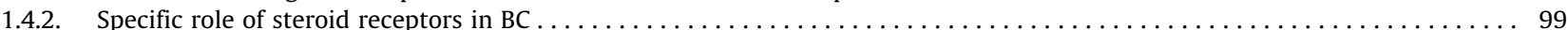

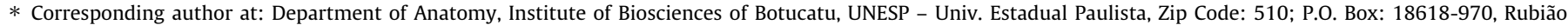
Júnior, s/n, Botucatu, SP, Brazil.

E-mail address: chuffa@ibb.unesp.br (Luiz Gustavo de Almeida Chuffa).
} 
1.5. Endometrial cancer . . .

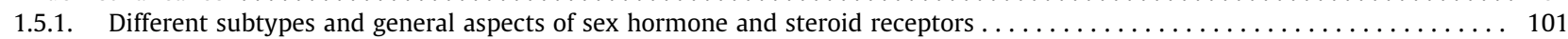

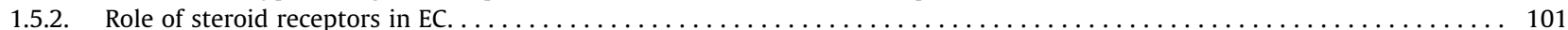

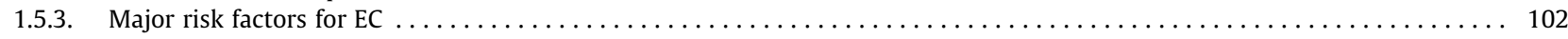

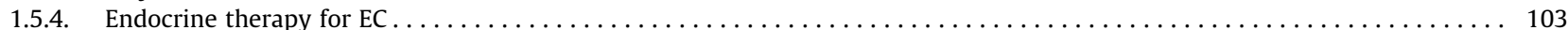

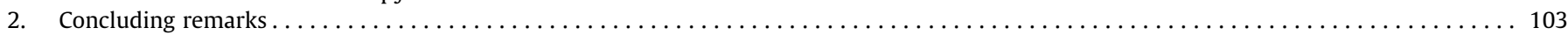

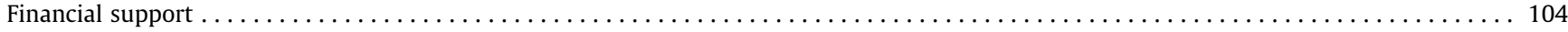

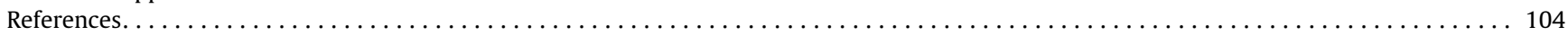

\section{Introduction}

\subsection{General overview of sex steroids and their receptors}

Estradiol (E2) and other sex steroid hormones circulate in the bloodstream specially bound to sex hormone-binding globulin (SHBG), a well-described glycoprotein synthesized by the liver $[1,2]$. The bioavailability of E2 to target cells is strictly related to SHBG. Sex steroids and their receptors have a profound involvement in diverse human diseases, including hormone-dependent tumors $[3,4]$. Estrogens promote physiological actions after binding to their estrogen receptors (ERs) subtypes (ER $\alpha$ and ER $\beta$ ). These receptors belong to the family of ligand-activated nuclear receptors. ER $\alpha$ is highly expressed in bone, reproductive organs, kidney, liver, and white adipose tissue, whereas ER $\beta$ is expressed in the prostate, ovary, bladder, uterus, and the central nervous system [5]. ERs share important domains with other members of the family, and N-terminal A/B domain is a specific region that confers direct actions on target genes. Notably, this region is responsible for the activation function-1 (AF-1) that is ligand independent, and promotes distinct cellular activities. The central C-domain is highly conserved in both ER $\alpha$ and ER $\beta$, and presents a DNA binding domain, which leads to receptor dimerization. The C-terminal Edomain represents the ligand binding domain (LBD) that contains AF- 2 region, and ER $\alpha$ and ER $\beta$ display a 59\% conservation [6]. ERs act as dimers to regulate gene transactivation, and this event is mediated by a synergic function between AF-1 and AF-2. Unlike $E R \alpha, E R \beta$ seems to have a weaker AF-1 function and is more dependent on the ligand for transactivation [7]. ERs can be activated by numerous ligands including ER activators such as tamoxifen and raloxifene, ER $\beta$ agonist diarylpropionitrile, ER $\alpha$ agonist propylpyrazole-triol, and other molecules [8]. Importantly, the estrogen response occurs after binding of ER to estrogen-responsive elements (EREs) followed by nuclear activation complex for the transcription of target genes. Estrogen can also exert their effects via non-genomic signaling through cell membrane ERs, which are regulated by downstream signaling molecules such as mitogen-activated protein kinase (MAPK), and protein kinases A and C [6].

The progesterone (P4) actions are dependent on progesterone receptor (PR), a member of the family of nuclear hormone receptor [9]. Essentially, PR is described with two isoforms, being the N-terminal-truncated $A$ (PRA) and the full length $B$ (PRB) [10]. In general reproduction, the progesterone responses are related to PRA in females, and conversely, PRB is essential for regulating normal proliferative responses [11]. P4 binding to PR elicits a structural change resulting in segregation of heat shock proteins, followed by dimerization, and binding to specific DNA promoter sites as P4 response elements. This process requires the participation of proper co-activators leading to transcriptional activation or repression [12].

Testosterone ( $\mathrm{T}$ ) acts through classical and non-classical signaling [13]. Although the well-known nuclear/cytosolic androgen receptor (AR), which works as a ligand-activated molecule, the involvement of AR in the non-genomic pathway remains controversial [13]. While a number of studies showed the main role of the nuclear/cytosolic AR in both classical and non-classical signaling pathways $[14,15]$, others evidenced a membrane-bound receptor from the GPCR family, as mediator of T-induced effects in different tissues and tumor cells [16-18].

\subsection{Sex steroids in pre and postmenopausal women}

In premenopausal women, E2 is largely produced by the granulosa cells of the ovarian follicle, and aromatase CYP450 enzyme is responsible for the conversion of $\mathrm{T}$ and androstenedione into $\mathrm{E} 2$ and estrone, respectively. The production of E2 is cyclical and regulated by feedback control to follicle-stimulating hormone (FSH), with fluctuations in the concentrations of E2 and P4 throughout the menstrual cycle during follicle development [19]. The expression of aromatase is common in peripheral tissues such as skin and adipose tissue, where activity is modulated by other signals including c-AMP, prostaglandins, and glucocorticoid [20]. After menopause, E2 and P4 output from ovaries decline, but the production of circulating E2 remains in the peripheral tissues. The concentration of E2 is not subject to large fluctuations in postmenopausal women [21], being fairly constant and low (10-60 pmol/l) in comparison to those observed in younger women (70-1500 pmol/l).

$\mathrm{T}$ is produced by the ovary, adrenal gland, and through peripheral conversion of androstenedione. Despite T decrease with aging, their levels do not appear to be severely affected by menopause [22]. In the early 1940s, T was reported to restore libido and ameliorates menopausal symptoms [23]. Recently, evidences have emerged on the hypothesis that the decline in $\mathrm{T}$ levels is linked to a decrease in libido, quality of life, and worse moods [24], and further exogenous androgens replacement associated with E2 can improve the symptoms affecting sexual function and related disorders [25].

Despite conflicting results, most postmenopausal women presenting high levels of hormones including E2, T, and estrone are at potential risk of developing ovarian, breast, and endometrial cancers (Fig. 1). Regarding tumor microenvironment, we also need to consider that external sources of estrogen and aromatase can drastically affect prognosis, especially in obese patients. In this line, adipose tissue inflammation associated with the recruitment of immune cells (e.g. macrophages) can favor the local production of estrogens in breast tissues, and it is possible that these effects may also be recognized in tumor-associated macrophages (TAMs) related to high expression of aromatase [26-28].

\subsection{Ovarian cancer}

\subsubsection{Different histotypes and the role of sex steroids}

Ovarian cancer $(\mathrm{OC})$ is the second most common and lethal gynecologic malignancy. Due to its advanced stage at the moment of diagnosis, OC presents with the highest mortality rate. About $90 \%$ of these subtypes are epithelial ovarian cancer (EOC), and unfortunately, $70 \%$ are late diagnosed with widespread metastasis [29]. Therefore, new therapeutic strategies and reliable screening 

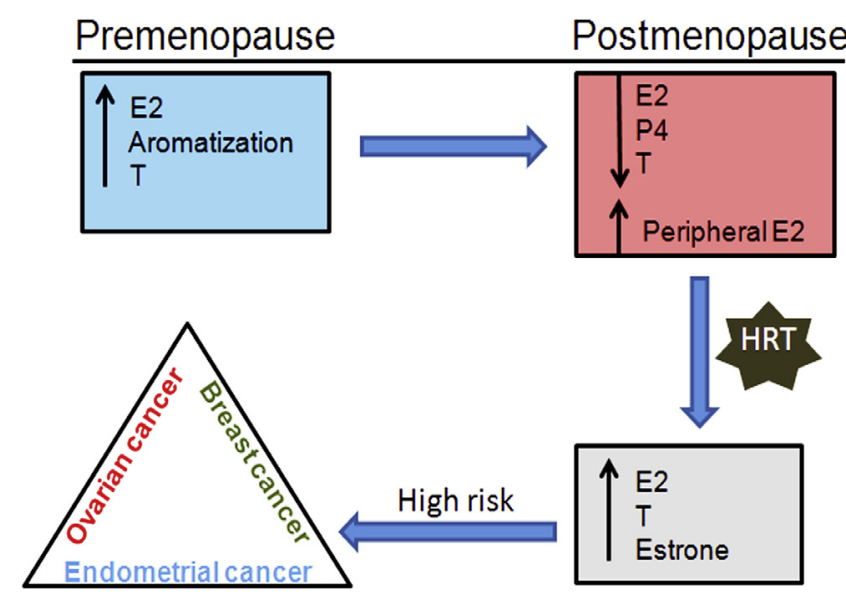

Fig. 1. Sex hormone profile in pre and postmenopausal women and the risk of developing ovarian, breast, and endometrial cancers. E2: 17 $\beta$-estradiol; T: testosterone; P4: progesterone; HRT: hormone replacement therapy.

methods for diagnosis are urgently needed. OC includes different histotypes with the most common being serous carcinoma, clear cell, endometrioid, and mucinous. These subgroups of tumors show distinct pathophysiological, genetic, and molecular components of the OC disease [30].

Sex steroid hormones (E2, P4, and T) are involved in the etiology of $\mathrm{OC}$, and there are associations between altered reproductive patterns affecting sex steroids and the development of OC. For example, pregnancy as a protective factor and the use of oral steroids may increase the risk related to HRT use [31]. Endogenous androgen levels at the pre-diagnostic stage are associated with the risk of OC [32]. Only one report shows P4 and E2 levels correlated with the risk of OC [33]. This is likely due to the large intra-individual changes of P4 and E2 during the menstrual cycle among premenopausal women, in contrast to low concentrations in postmenopausal women [34]. It has been recently demonstrated that androgen concentrations positively correlated to the elevated risk of developing serous and mucinous OC, whereas higher E2 levels was related to endometrioid tumors. However, no relationship between E2 and T and the risk of high-grade serous or clear cell histotypes were observed [35]. High androgen levels in pre- and postmenopausal stage correlate with the increased risk of OC initiation. During menopause, the androgens are the main steroid source produced by the ovaries and the incidence of $\mathrm{OC}$ is considerably increased [36]. Non-epithelial OCs account for $10 \%$ of all ovarian tumors [37]. They represent two major subtypes, the germ cell and sex cord-stromal tumors [37,38]. While sex cord-stromal tumors may appear in women at all ages [38] and show a median age of 52 years at diagnosis, germ cell tumors appear predominantly in young women around 18-25 years old [39]. Recently, epidemiological evidences reported that elevation in steroid levels during pregnancy, particularly the androgens, may be a direct cause of high risks of developing sex cord-stromal tumors. Concentration of T, androstenedione, and 17-hydroxiprogesterone during the early part of the last pregnancy and preceding OC diagnosis was associated with tumor development [40]. Regarding all OC malignancies, the sex cord-stromal tumors are steroid-producing tumors and represent only $0.1 \%$ of the incidence rate [41]. These OC subtypes include Leydig cell tumor, stromal luteoma, and steroid cell tumor [42], and they produce hormones such as E2 and T; and excess of E2 can lead to postmenopausal bleeding. After reduction surgery, the serum levels of $\mathrm{T}$ often decrease in approximately $25 \%$ of the steroid-producing tumors [43].

\subsubsection{Sex steroid receptors and prognosis}

The interplay between E2 and ERs has been considered as one of the major causes of OC. Past studies have detected a dual expression of their isoforms ER $\alpha$ and ER $\beta$ in normal ovary, whereas an increase in ER $\alpha$ expression and the complete absence of ER $\beta$ expression were found in aggressive tumors [44]. Importantly, the ER $\alpha$ is continuously expressed in approximately 70\% of OCs, and targeting this receptor represents a potential treatment for these tumors [45]. In addition, ER $\beta$ and PRs were identified in approximately $75 \%$ and $20 \%$ of OCs, respectively [46]. There is a positive correlation between ER $\alpha$ expression and levels of intratumoral TAMs, irrespective of menopausal status. This relationship indicates that in ER $\alpha$-positive OC, local E2 may affect the interaction between cancer cells and stroma, further promoting TAM accumulation [47]. Possibly, membrane-associated estrogen receptors such as ER $\alpha 46, \mathrm{ER} \alpha 36$, and G protein-coupled ER1 (GPER) may also be involved in OC progression [48]. Fig. 2 illustrates some genomic and non-genomic effects by which different steroid receptors are potentially involved in the development of OC.

In ovarian tumor microenvironment, E2 stimulates cell proliferation, and its potential to be differentiated and transformed [49]. Furthermore, E2 plays a role in OC by preventing cell apoptosis. In these cells, E2 upregulated bcl-2 gene and prevented tamoxifen induced-apoptosis through ER [50]. In Caov-3 human ovarian cancer cells, E2 changed the effects of paclitaxel upon apoptosis and reversed the reduction of cell viability [51]. Also, E2 increased the onset of $\mathrm{OC}$ and decreased survival rate in a rodent model of OC by changing the pathophysiology and distinctive papillary pattern of tumors [12]. In contrast, patients with PR-positive OC showed significantly more favorable prognosis than those with PR-negative tumors [52]. It has been proposed that the loss of ER $\beta$ expression is an important mechanism in the development of OC, and ER $\beta$ expression appeared to be significantly higher in early stages of OC rather than in advanced stages [53]. Moreover, higher ER $\beta$ expression was correlated with longer-free survival rate [54]. While loss of ER $\beta$ in OCs may be associated with malignant phenotype, the expression of PR represents a good prognostic biomarker. Regarding the expression of PRs, a recent meta-analysis involving 35 different cases indicated better outcomes of OC after elevation in the PR levels [55]. Interestingly, an OC consortium study analyzed tissues from 2933 women with different tumor subtypes and reported that PR expression improved survival rate for high-grade serous OC and endometrioid carcinoma; however, no correlation was observed for the other types [45]. These effects may be attributed to the fact that PR stimulates apoptotic cell death in OC cells, which could ameliorate the survival rate in PRpositive tumors [56]. Additionally, the activation of nuclear PR by progestins is able to upregulate the Forkhead-box transcription factor (FOXO1), leading to induction of cell cycle arrest by increasing cell cycle mediators of senescence [57]. Nevertheless, the status of PR-positive tumor was considered to be an independent valuable tool of improved survival rate regardless of OC types. The crosstalk between ER and PR has been widely described in gynecological tumors [58] and provides important information for ovarian cancer outcomes. Escobar et al. [59] observed that low-grade serous OCs express higher levels of these receptors than high-grade serous OCs ( $58 \%$ vs. $27 \%$ of ER and $43 \%$ vs. $17 \%$ of PR, respectively), suggesting that low-grade serous OC may respond to chemotherapy similarly to $\mathrm{ER}+/ \mathrm{PR}+$ breast tumors [60]. It is quite difficult to find a direct correlation between the histological subtypes of $\mathrm{OC}$ and the expression profile of ERs and PRs. Therefore, additional studies describing the relationship between sex hormone and steroid receptors and the clinical aspects for individual histotype of OCs are needed to make a better decision during the application of an endocrine therapy. 


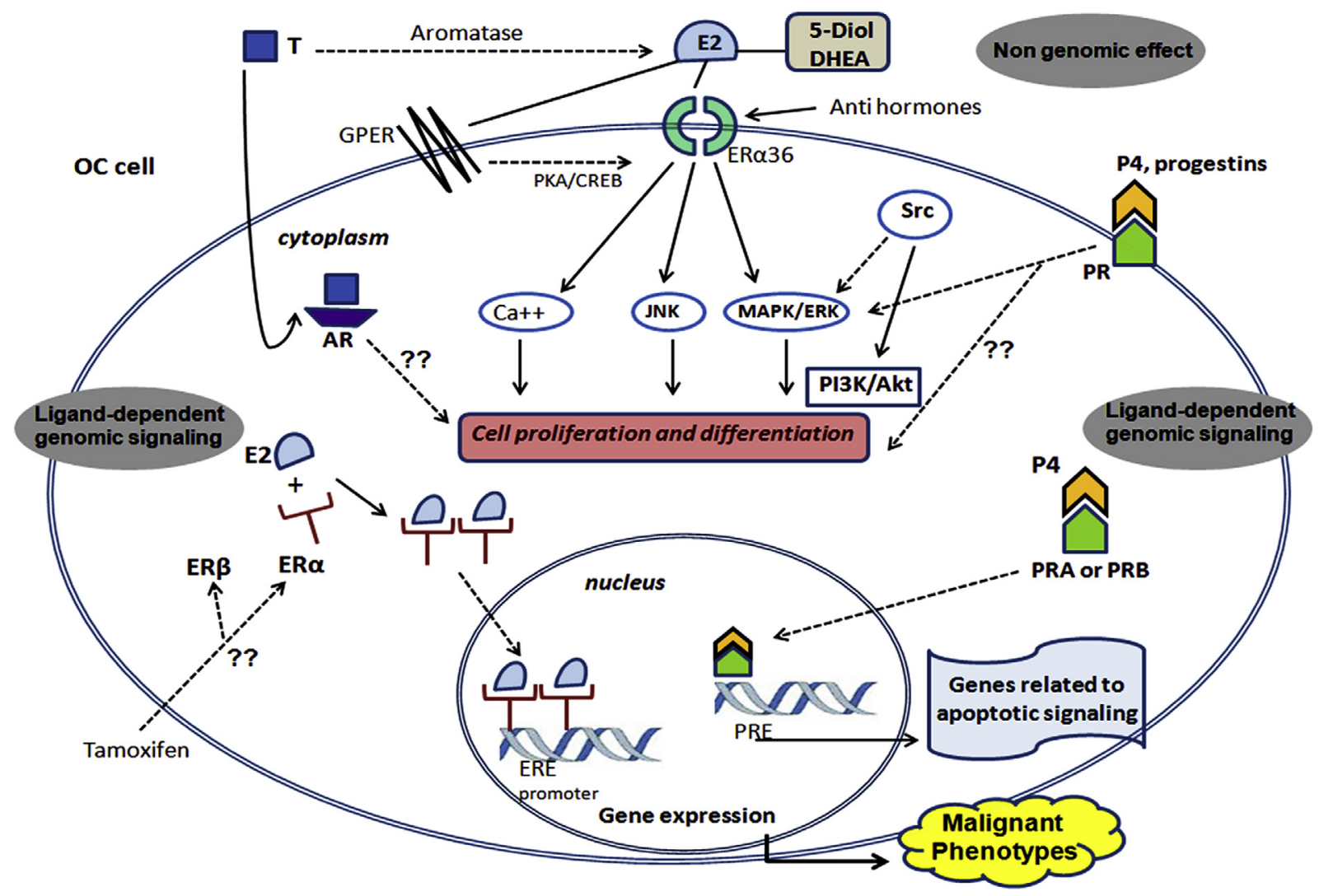

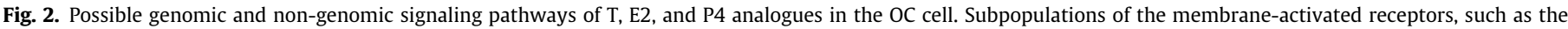

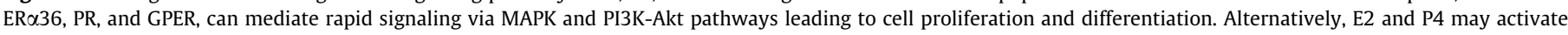

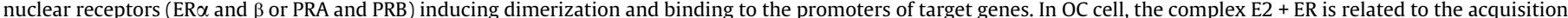

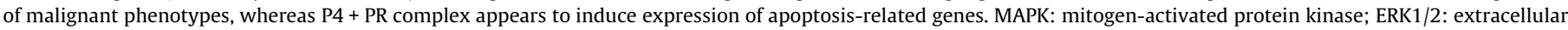

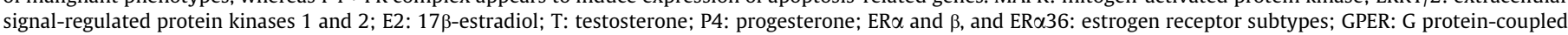

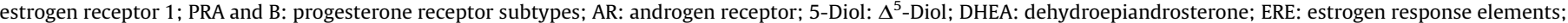
PRE: progesterone response elements; ??: unclear actions.

\subsubsection{Hormone replacement therapy and the risk factor for $\mathrm{OC}$}

Hormone replacement therapy (HRT) as a treatment for the symptoms of menopause in women aged 50 years showed an important increase in 1990s, but decreased significantly around 2000s, when the Women's Health Initiative published the increased risk of breast cancer, coronary heart disease, stroke, and pulmonary embolism in women using HRT [61]. Current HRT guidelines vary in what they say about ovarian cancer, but the majority still consider that there is insufficient evidence about the risks for this type of cancer. However, those guidelines were published before the new study from the Collaborative Group on Epidemiological Studies of Ovarian Cancer (CGESOC) analyzing data from 52 epidemiological studies in different countries of Europe and North America. The CGESOC study finally showed an elevated risk of developing OC in women who received HRT for menopausal symptoms [62].

HRT can be administered as unopposed estrogens (estrogen therapy - ET) or as an association between estrogens and progesterone (estrogen/progesterone therapy - EPT). There is a strong relationship between unopposed estrogen therapy and increased OC incidence [63-65], but it is still unclear if the combination estrogen/progesterone plays a role in OC development. Although a lower risk has been reported for OC development in women with continuous progestin use [66], other studies showed an increased OC risk in women who underwent continuous estrogen/progestin therapies $[67,68]$. In fact, a large prospective analysis by Trabert et al. [69] reported that long-term treatments with either unopposed estrogen or estrogen/progesterone increased the risk of developing ovarian carcinoma, suggesting that the addition of progestin does not attenuate ovarian cancer risk, even with continuous administration.

Recently, the CGESOC analyzed data from 52 epidemiological studies from 1977 to 2013 . The report showed that OC risk was increased in women using HRT, regardless of the duration of treatment, as even in users with less than 5 years of HRT use, there was still a significantly increased risk of developing this cancer. The analyses of former users of HRT showed that the risks decreased over the years after the last dose, but even 10 years after ceasing therapy, there still seemed to be an important risk. Importantly, the study showed that no difference exists between the unopposed estrogen and estrogen/progesterone therapies, both significantly increasing the risks of developing OC. Interestingly, a substantial variation by the tumor subtype was observed in this study: HRT increased the two most common epithelial lesions, serous and endometrioid tumors, and decreased the other two types, clear-cell and mucinous tumors $[68,70]$. The findings about the increased risks of OC in women using HRT, even with less than 5 years of use, are relevant to review the current patterns of HRT use and should be considered for medical advice and worldwide guidelines publications. However, note that HRT is a well used effective treatment for vasomotor symptoms during the menopausal period and should be considered being administered in its lowest effective doses [65]. 


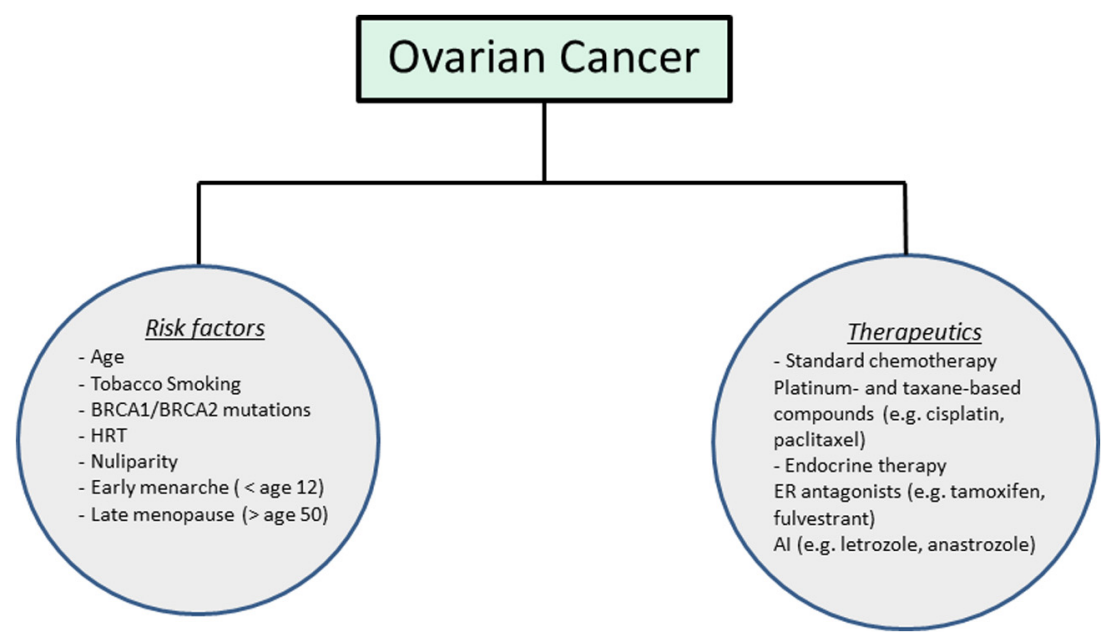

Fig. 3. Most risk factors and therapeutics used in the treatment of OC.

\subsubsection{Endocrine therapy for $O C$}

OC accounts for numerous deaths than any other female reproductive cancer. Unfortunately, the American Cancer Society estimated that about 22,280 new cases of OC will be diagnosed and 14,240 women will die of OC in the United States in 2016 [71]. The advanced stage of the disease at diagnosis and the development of chemoresistance to standard chemotherapeutic regimens (platinum- and taxane-based therapies) represent a big challenge to treating ovarian cancer, contributing to its 5-year survival rate that remains only at $45 \%$ [72]. The second-line treatment for recurrent $\mathrm{OC}$ is chosen based on initial response to chemotherapy, but the majority of these patients will face multiple regimens of cytotoxic drugs such as gemcitabine or liposomal doxorubicin. These chemotherapy options come with a number of adverse effects and patients frequently die of progressive disease [73-75]. Blocking or altering the estrogen pathway has been described as a good alternative for treating breast and uterine cancers and could also represent an effective target for ovarian cancer due to low toxicity, high acceptance and tolerability of anti-estrogen and aromatase inhibitor therapies particularly in post-menopausal patients [76,77]. Fig. 3 summarizes most OC risk factors and major therapeutic strategies.

For several years, second-line therapeutic alternatives with low cytotoxicity have been studied. Antiestrogen compounds, such as ER antagonists (e.g. tamoxifen, fulvestrant) and aromatase inhibitors (e.g. letrozole, anastrozole, exemestane) are used to counteract the ER-positive breast tumors. Thus, as both normal and neoplastic ovarian tissues express ERs, these hormonal therapies could display some positive effect in OC. Tamoxifen is an estrogen agonist that competitively binds to ER, blocking the effects of E2, thus preventing pro-tumor signaling from ER $\alpha$ activation [78]. However, some recent studies have described potential non-estrogen-dependent mechanisms for tamoxifen, which are important for ER-negative OC. Tamoxifen therapy is able to cause cell cycle arrest by upregulating both p21 and p27 in ER-positive breast cancer cells [79]. In a recent study, tamoxifen induced cell cycle arrest by up-regulating p16 and p21, and triggering apoptosis in an OC cell line [80]. Despite promising effects in OC cell lines and xenograft models, the mechanism(s) of tamoxifen remains unclear in human OC, and its use in patients did not reach desirable rates of responsiveness. Another anti-estrogen in use is the pure ER-antagonist fulvestrant. Similar to tamoxifen, it has also been showed to induce cell cycle arrest by induction of p27 in OC cells [81], but yielded low response rates (mean $8 \%$ ) with only $35 \%$ disease stabilization in a small phase II trial [82]. The results on fulvestrant use have been frustrating, although a recent study targeting the Src mitogenic pathway related to cell proliferation and apoptosis in OC $[83,84]$ showed that the inhibition of this pathway reverted fulvestrant resistance [81], thus, supporting new evaluations on the association of antiestrogen with Src inhibitors.

Aromatase is a key enzyme responsible for converting androstenedione into estrogen in different tissues. This protein is highly expressed in muscle, fat, liver, brain, breast tissues, and breast and ovarian cancers, and its estrogen production is the predominant source of the hormone in postmenopausal women $[85,86]$. This in situ aromatization is the major source of estrogen for tumor tissues, acting as an autocrine factor for cancer cell growth and proliferation independent of circulating estrogen levels [87]. Because aromatase is expressed in $33-81 \%$ of OCs [88,89], a number of researches are evaluating the role of aromatase inhibitors (AIs) for recurrent OC treatment. The most used component of this class is letrozole, which is able to reduce estrogen production by $90 \%$ in postmenopausal women and is reported to be better than tamoxifen as a complementary therapy in breast cancer [90]. Note that a recent study by Hirakawa et al. [91] reported that letrozole decreased VEGF and MVD levels in ovarian cancer cells, thus inhibiting angiogenesis, and consequently, decreased OC cell proliferation. Importantly, a number of investigators have reported that ER expression should be considered as a predictor for aromatase inhibitor response as they have had better responses in patients with elevated levels of ER [91-93].

It is undisputed that estrogens have an important role in driving the proliferation of OC cells in xenograft models and cell culture [81,94-96]. ER $\alpha$ is a well-known nuclear receptor that acts as a transcriptional factor for a number of genes regulating cell proliferation and survival, which could facilitate tumor promotion and progression [97]. A previous study showed that ER $\alpha$ activation by either E2 or a receptor specific agonist induces cell proliferation [77]. In addition, another study reported that this effect is not observed when an ER $\beta$ specific agonist is used $[5,81]$, evidencing that estrogens could favor OC development through ER $\alpha$-mediated effects. Because the activation of ER $\beta$ by a highly selective agonist led to inhibition of SKOV-3 OC cells [98], it would be an interesting approach to target the ER $\alpha / E R \beta$ balance in ER-positive subtypes of OC so that patients could take the advantage of an association of ER $\alpha$ antagonists, ER $\beta$ agonists, and even aromatase inhibitors to increase their chances of an effective treatment response. 


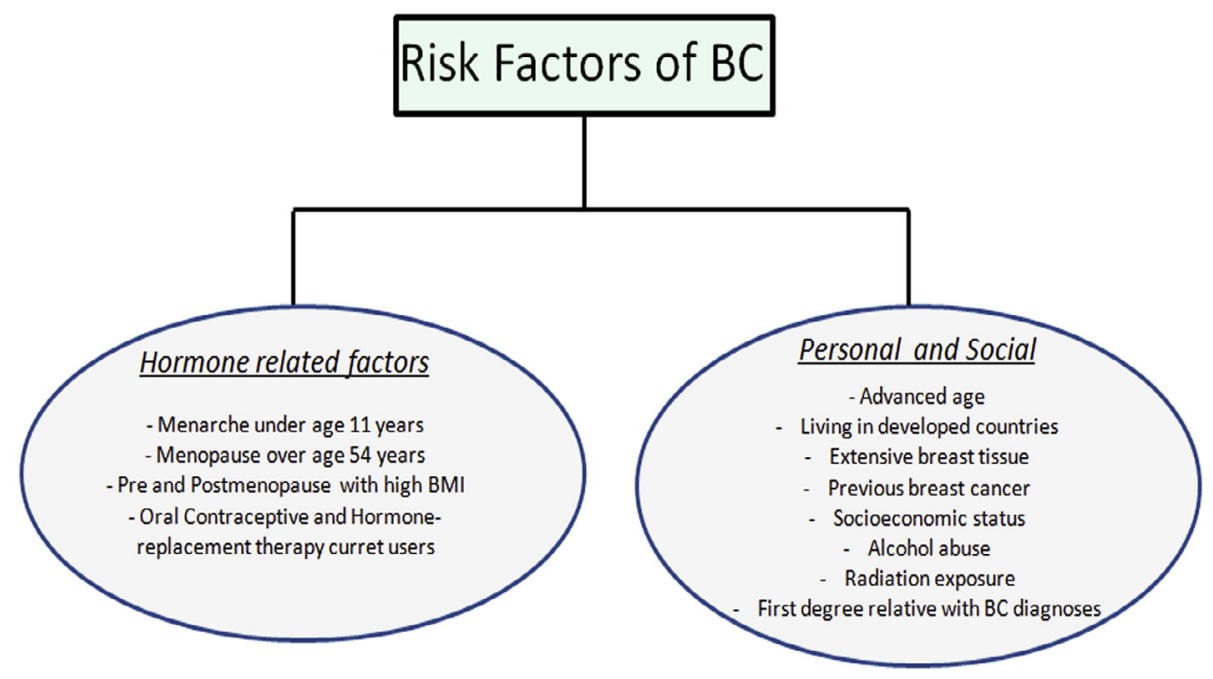

Fig. 4. Important risk factors associated with the development of BC.

\subsection{Breast cancer}

\subsubsection{Risk factors and general aspects of sex hormone and steroid receptors}

Despite the remarkable progress in the treatment of breast cancer (BC) over the past decades, this disease is still one of the most leading causes of death among women [99], and is certainly a public health issue accounting for $25 \%$ of all cancers in females worldwide [100]. Although the mortality rates are falling in most European countries, as well as in South and North America [101], the American Cancer Society estimated 246,660 new cases of invasive and 61,000 in situ BC in 2016. As with other cancer types, the best way to achieve success in $\mathrm{BC}$ treatment is early diagnosis, so that several efforts are guided to the identification of risk factors. Nonetheless, BC is a heterogeneous and complex disease and the relative risk factors are still open for debates [102]. Fig. 4 highlights some risk factors for $\mathrm{BC}$, and as indicated, the hormonal influences must be considered. Besides the hormonal status itself representing a strong factor for $\mathrm{BC}$ prognosis, the hormone receptor profiles are growing in consensus and some studies have drawn attention to this $[103,104]$. Thus, an elucidation on how the hormone/receptor balance might interact is particularly relevant since over $30 \%$ of BC patients show resistance to endocrine therapies [105].

Doisneau-Sixou et al. [106] reported the role of sex hormones in the regulation of physiological functions of the reproductive and non-reproductive systems, and pointed out that the development and growth of mammary glands is closely linked to E2 and ERs. Generally, estrogenic effects are induced by classical ligand-activated transcription factors through genomic pathways, including ER $\alpha$ and ER $\beta$ [107], but now, it has been already demonstrated that non-genomic pathways are also relevant for mammary tissue homeostasis [108]. ER $\alpha$ is also known as NR3A1 (nuclear receptor subfamily 3, group A, member 1 ), and ER $\beta$, is the member 2 of this group [109]. The proteins contain 595 amino acids and its gene is located on chromosome 6, and 548 amino acids are located on chromosome 14, respectively. The canonical ER pathway involves estrogen binding to ERs which undergo conformational changes [108]. The response to ER can also lead to transcription of genes at non-ERE DNA binding sites [110], as well as estrogen response may be triggered by truncated, splicing variant forms of ER $\alpha$, such as ER $\alpha 46$ and ER $\propto 36$, predominantly membrane-based ERs that are capable of mediating rapid estrogen-induced signaling pathways [111]. These activations are now recognized as important pathways regulating the estrogenic effects in BC, including cell proliferation, metastasis and invasion.

Notably, ERs are not the only receptors related to breast tumorigenesis, but also the following: PR, GPER, G protein-coupled ER (formerly GPR30) [107], epidermal growth factor receptor (EGFR) [112], and human epidermal growth factor receptor 2 (HER2) [113]. These are the most important regulators during BC progression and diagnosis. In this context, breast cancers are often classified as luminal A, low proliferation rate (ER- $\alpha$ positive, PR positive); luminal $B$, high proliferation rate (ER $\alpha$ positive, PR positive); HER2 overexpressing and triple negative $\mathrm{BC}$, meaning that they are absent for ER $\alpha$, PR and HER2 [114,115]. It would be more plausible to consider the tumor microenvironment as well as other receptor patterns to achieve a more accurate classification. BC patients are frequently separated in ER $\alpha$ negative and ER $\alpha$ positive breast cancers. Recently, a study conducted by Zhang et al. [116] showed that nearly $70 \%$ of BC are ER $\alpha$ positive which could explain some of the beneficial effects achieved with adjuvant drugs during treatment, which include selective estrogen receptor modulators (SERMs; i.e. tamoxifen), selective ER downregulators (SERDs; i.e. fulvestrant), aromatase inhibitors (AIs) (i.e. anastrazole) [108]. Furthermore, estrone, E2, and many xenoestrogens such as phytoestrogens, environmental and pharmaceutical estrogens, can trigger specific estrogen-related responses. Nonetheless, intrinsic resistance to endocrine therapies has been demonstrated for BC. This resistance could be explained by ER $\alpha$ mutations, aberrant activity of co-regulatory proteins, constitutive activation of growth factor receptors, downregulation of pro-apoptotic signaling pathways, alteration in DNA response process, upregulation of pro-survival autophagy, and more recently, the participation of the unfolded protein response (UPR) [115,117]. In this scenario, the understanding of regulatory and molecular mechanisms and the search for new candidate drugs are ongoing and is quite important for a better and more precise $\mathrm{BC}$ treatment. Table 1 lists some studies regarding the benefits and side effects of $\mathrm{BC}$ treatment with classic anti-estrogen compounds, tamoxifen and anastrazole, and some experimental studies with other possible future treatments.

Notwithstanding, the mechanisms involved in BC biology are complex and evoke several different, interrelated intracellular pathways, and hormonal signaling. Some in vitro studies have showed ER $\alpha$, ER $\alpha 36$ and ER $\beta$ activation to have different responsiveness to BC. Basically - and very concisely - ER $\alpha$ promotes cell proliferation; ER $\beta$ acts as anti-proliferative and anti-invasive sig- 
Table 1

Different drug treatments, receptor status, and main outcomes in BC.

\begin{tabular}{|c|c|c|c|}
\hline Drugs & Receptor status/cells & Results & Study \\
\hline Tamoxifen & $\begin{array}{l}\text { DCIS ER positive } B C \\
\text { DCIS ER negative } B C \\
\text { ER negative/AR positive } B C \\
\text { ER negative/AR negative } B C\end{array}$ & $\begin{array}{l}\text { Significant reduction in } B C \text { recurrence at } 10 \text { years and over- } \\
\text { all follow-up } \\
\text { No significant benefits } \\
\text { Decreased recurrence rate } \\
\text { No difference in recurrence-free survival } \\
\text { Did not alter the recurrence rate No difference in recurrence- } \\
\text { free survival }\end{array}$ & Allred et al. (2012) \\
\hline $\begin{array}{l}\text { Tamoxifen } \\
\quad \text { X } \\
\text { Anastrozole }\end{array}$ & $\begin{array}{l}\text { ER positive/PR positive DCIS } \\
\text { ER positive }\end{array}$ & $\begin{array}{l}\text { No difference in recurrence rate } \\
\text { Side-effects profile differed } \\
\text { Similar objective response } \\
\text { Increased time to progression for anastrazole treatment }\end{array}$ & $\begin{array}{l}\text { Forbes et al. (2016) } \\
\text { Nabholtz et al. (2000) }\end{array}$ \\
\hline Curcumin and Resveratrol & TNBC & Low effectiveness in clinical settings & Shindikar et al. (2016) \\
\hline Geftinib (D1839) & MCF-7 cells & Inhibition of EGFR and reduced invasion and motility & HIscox et al. (2004) \\
\hline Dendrogenin (DDA) & TSA cells & Reduce tumor growth and improved mice survival & Silvent-Poirot et al. (2016) \\
\hline
\end{tabular}

naling; ER $\alpha 36$ can inhibit genomic estrogen signaling in such a way that ERa36 must be regulated differentially and strictly to maintain a normal estrogen signaling [108,115]. As an expected estrogen-dependent tumor, the proliferation rate and growth of $\mathrm{BC}$ are regulated by estrogens or other active molecules mimicking the estrogen effects. Despite the increasing use of anti-hormones treatment in adjuvant therapy, a considerable number of patients still develop BC recurrence [118], reinforcing the need to improve our understanding on how ER and steroid hormones act upon one another and to better establish the right drug to the right patient [103].

\subsubsection{Specific role of steroid receptors in $B C$}

$\mathrm{ER} \alpha$, a nuclear receptor for the steroid hormone estrogen, was first cloned from the MCF-7 human breast cancer cell line by Walter et al. [119]. It regulates the development and differentiation of the mammary tissues, and is frequently found to be overexpressed in BC $[120,121]$, in such a way that it is routinely applied as an important biomarker during diagnosis and molecular therapy target $[120,122,123]$. ER $\alpha$ is known as the major drug target in hormonal BC, and therapies include the blockage of estradiol and its receptor, by the non-steroidal antiestrogen tamoxifen, or the inhibition of estrogen synthesis, by aromatase inhibitors, such as ICI 182,780 [124].

After association of E2 with ER $\alpha$ (or after ER $\alpha$ phosphorylation), which facilitates ER $\alpha$-chromatin interaction, some upstream transcription factors are able to bind ER $\alpha$, such as FOXA1, PBX1 and AP$2 \gamma$ [125-127]. Once ER $\alpha$ binds to chromatin, several members of the p160 co-activator family are recruited forming the p160/ER $\alpha$ complex, which is essential for the correct DNA transcription [128]. Interestingly, treatment with tamoxifen interferes with the correct transcription of the p160/ER $\alpha$ complex [129]. Increasing evidences have pointed to an important association between different steroid hormone receptor family members (i.e. PR and AR) and glucocorticoid receptor (GR). AR is often expressed in ER positive $B C$ [130] and also in a subset of ER negative BC $[131,132]$. Although AR overexpression has been thought to favor BC outcomes [133], some recent data provided important evidence that actually, AR expression could act as a driver for ER positive BC therapy resistance. Cochrane et al. [134] reported the importance of AR/ER ratio in BC prognosis, characterizing tumors with similar levels of AR to ER as more responsive to neoadjuvant endocrine therapy. On the other hand, decreased levels of ER compared to AR could suggest the switch of tumors from a state of estrogen dependence to androgen dependence [135,136]. In this scenario, ER positive BC could benefit from endocrine therapy with AR signaling inhibitors (e.g. enzalutamide) or aromatase inhibitors
[134]. AR overexpression can lead to endocrine resistance by activating survival pathways, such as AKT/IGF-1R signaling pathways $[135,136]$. In addition to anti-androgen therapy, inhibitors of those pathways could help in restoring endocrine sensitivity in resistant $\mathrm{BC}$ [137]. The co-expression of PR in ER $\alpha$-positive BC is also associated with favorable outcomes and regulates chromatin-ER $\alpha$ interaction at the transcriptional level $[138,139]$. The interaction between GR and ER $\alpha$, in the presence of dexamethasone, inhibits the cellular growth of some tumors [140]. Note that the interplay among these receptors may affect nuclear receptor activity [127].

$E R \alpha$ and its respective EREs may also be modulated at the phosphorylation level and is related to different prognosis [141]. Different protein kinases are involved in this process, such as CDK2, ERK 1/2, EGFR, IGF1R, AKT, CK2, PKA and PAK1; each one acting in different serine residues [127]. De Vries-van Leeuwen et al. [142] demonstrated a 594 threonine phosphorylation at ER $\alpha$ to influence gene expression after E2-ER $\alpha$ stimulation. Briefly, ER $\alpha$-positive BC cell lines and different tumors shared several ER $\alpha$-binding sites but their clinical implications still need to be clarified [127].

ER $\beta$ was first discovered in the rat prostate in 1996 [143], and belongs to the nuclear receptor family composed of numerous transcriptional factors, and regulated by steroidal ligand. ER $\beta$ is more abundant in normal mammary glands than ER $\alpha$ [144], and is widely described in basal and luminal epithelial cells, adipose cells, lymphocytes, fibroblasts, and endothelial cells [98]. In vitro and in vivo studies have suggested ER $\beta$ actions to be anti-ER $\alpha$, antiproliferative, and pro-apoptotic [113,145]. In MCF-7 cultured cells, the overexpression of ER $\beta$ leads to a reduction in the proliferation rate in response to E2 which was more evident after repressing c-myc, cyclin D1, and cyclin A gene transcription, while increasing the expression of p21 and p27, leading to G2 cell cycle arrest [98,146].

High ER $\beta$ expression is sometimes linked to better BC outcomes [113]. Curiously, ER $\beta$-positive cells are markedly decreased during the transformation of normal breast tissues to ductal carcinoma in situ (DCIS), while ER $\alpha$-positive cells tend to be increased. The ER $\beta / E R \alpha$ ratio declines also from DCIS to IDC (invasive ductal carcinoma). Differently from ductal BC, the lobular BC has both ERs highly expressed with low proliferating rates, suggesting lobular cancer as a result of anoikis resistance more than those with high proliferative pattern. The ER $\beta$ agonist was reported to prevent DCIS from its potential to be invasive in a study investigating the expression of ER $\alpha, E R \beta 1$ and ER $\beta 2$ in surgically excised breast tumor samples [144].

Similar to ER $\alpha, E R \beta$ can be regulated by phosphorylation. EAY2 phosphatase and c-ABL tyrosine kinase regulate the rate of a (36) tyrosine residue phosphorylation, which is present only in the 
ER $\beta$ subunit, and seems to be needed for the ER $\beta$ to bind to its promoter sites. In this context, the higher content of the phosphorylated form in human BC samples was strongly related to both disease-free and overall survival rate of patients [147]. Although conflicting results are found, it can be assumed that ER $\beta$ interferes with the ER $\alpha$ function as well as promotes downregulation of its downstream genes. Moreover, the presence of ER $\beta$ alters the sensitivity to drugs that directly bind ER $\alpha$, such as raloxifene or tamoxifen [98]. Note that following endocrine therapy, a considerable number of BCs develop resistance against these compounds. In this regard, ER $\beta$ expression needs to be stimulated whereas ER $\alpha$ expression needs to be inhibited. Besides the stimulation by ERs, cell growth may be regulated by other signaling pathways in BC, such as PI3K/Akt/mTOR pathway [148], opening an avenue for new candidate drugs (e.g. mTOR inhibitor everolimus; [149]).

Different from ER $\alpha$ and $E R \beta$, the ER $\alpha 36$ is a membrane estrogen receptor (mER) that is not expressed in normal breast cells but overexpressed in neoplastic mammary cells, revealing the importance of this receptor for breast tumorigenesis (Fig. 5). Some xenoestrogens are able to bind $\mathrm{MER}$ during $\mathrm{BC}$ progression, thus influencing cell cycle, proliferation, survival, cell migration and invasion [108]. ER $\alpha 36$ expression in BC is related to MAPK/ERK and PI3K/Akt pathways, which in turn cause the hyperproliferative and anti-apoptotic behavior of these cells. Furthermore, mER- $\alpha 36$ is able to interact with different membrane receptors leading to a non-genomic estrogen response that accounts for a different responsiveness in $\mathrm{BC}$ treatment (Fig. 5). Regarding ER expression, the results of endocrine therapies demonstrated that tumor overexpressing ER $\alpha 36$ has been proven to slow the progression with chemotherapy, and ER $\alpha 36$ negative tumors that received neoadjuvant chemotherapy have better prognosis [150]. For example, tamoxifen therapy has limited efficacy in women who are positive for ER $\propto 36$ [151], even in ER $\alpha$ negative BC patients, suggesting that tamoxifen is unable to prevent the non-genomic signaling pathway induced by the ER $\alpha 36$ [111]. Aromatase inhibitors, such as fulvestrant (ICI 182,780) also failed to inhibit cell proliferation and related downstream pathway initiated by ER $\alpha 36$ [152]. Taken together, these results clearly suggest that the success of endocrine therapies for $\mathrm{BC}$ relies on the receptor profile.

Estrogen-related receptors (ERRs) represent a subfamily of orphan nuclear receptors, divided into 3 subtypes termed ERR $\alpha$, ERR $\beta$ and ERR $\gamma$ [153]. ERR can contribute to estrogen responsiveness since they share some DNA binding site with ER, making them potential targets for chemical treatments and prognostic biomarkers of estrogen-related cancers [154]. These receptors are involved in cellular energy metabolism [155], and increased expression of ERR $\alpha$ was found in specific BC subtypes [156]. Nonetheless, the role of ERR in BC is still controversial and relies upon the receptor status of tumor cells. For instance, ERR $\alpha$ affects sensitivity to tamoxifen depending on ER-positive or ER-negative status, which lead us to conclude that ERR $\alpha$ activity working as transcriptional activator or repressor is linked to cellular state [156]. ERR $\beta$ signaling acts as a tumor-suppressor in BC by blocking the G1/S transition mediated by BCAS2 so that cellular proliferation is inhibited [157]. ERR $\gamma$ response seems to be hormone- and dose-dependent and this receptor interacts with ER $\alpha$ to act with other molecules such as angiogenin [158]. In this regard, angiogenin acts as a novel potential therapeutic target since its binding to ERR $\gamma$ gene results in severe inhibition of BC cell proliferation [159].

The G protein-coupled receptors (GPCRs) are important and versatile membrane molecules encoded by one of the largest families of genes reported in human genome. The members of this family are responsible for transducing extracellular signals to het-

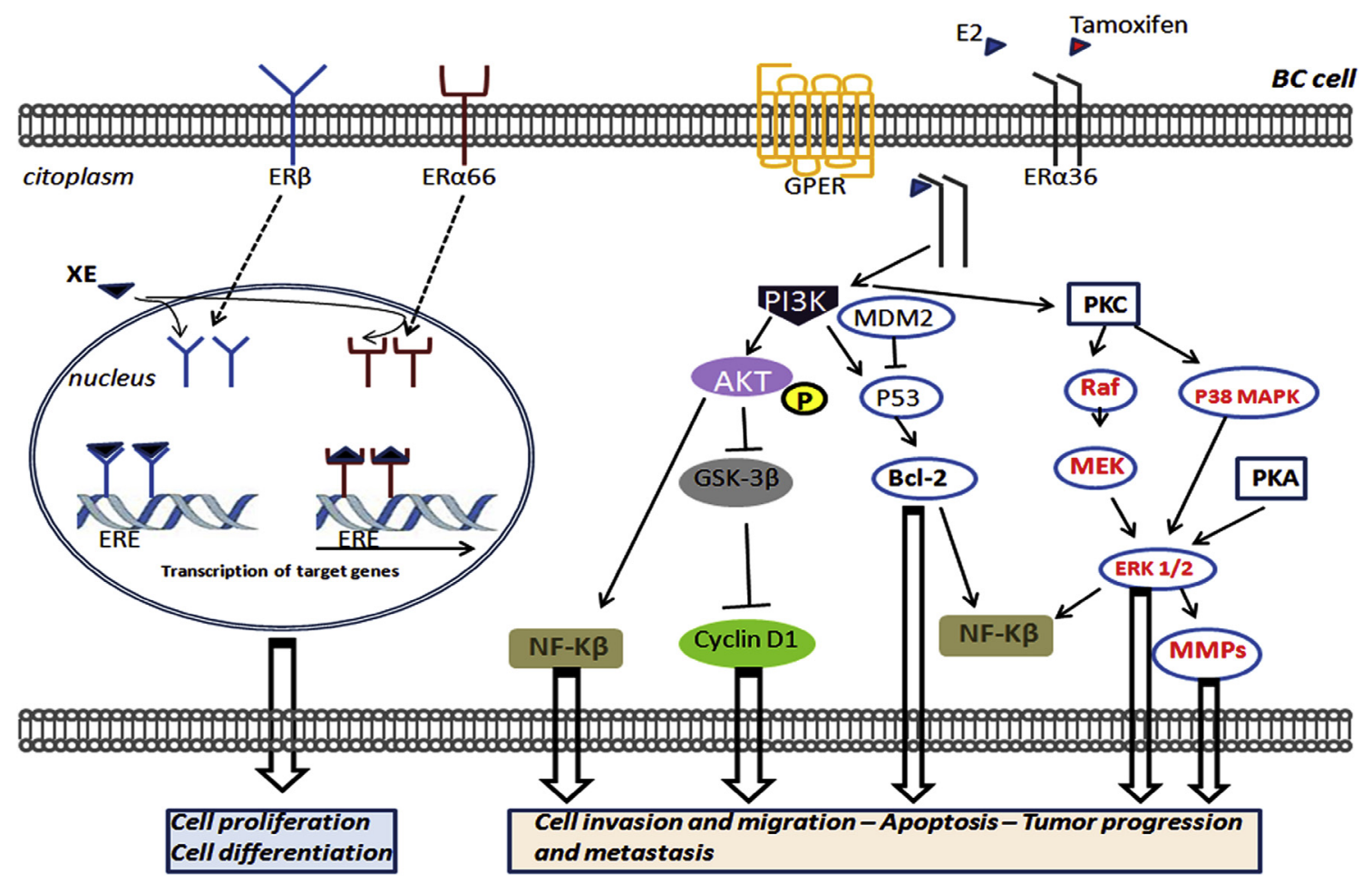

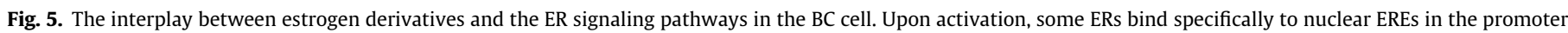

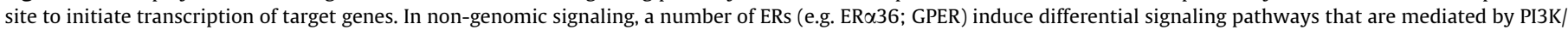

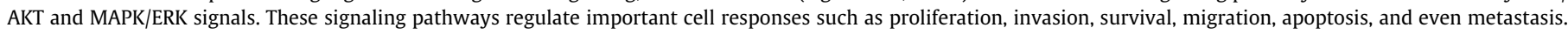

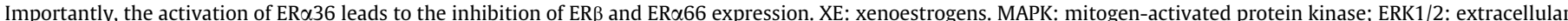

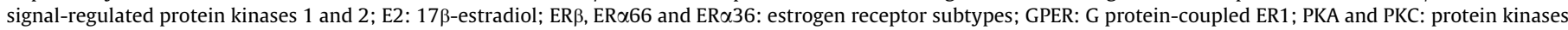
$A$ and C; MMPs: matrix metalloproteinases; NF-K $\beta$ : nuclear factor kappa Beta; ERE: estrogen response elements. 
erotrimeric G proteins (Fig. 5). GPER signaling includes mitogenactivated protein kinase (MAPK), extracellular signal-regulated kinase (ERK) and phosphoinositide 3-kinase (PI3K) pathways [107]. GPER is widely expressed in human tissues, including breast [160], and the GPER-mediated signaling pathways are described to be involved in neoplastic transformation in estrogen-dependent cancers [161]. Recent evidence suggests that GPER regulates cancer cell proliferation [162]. Furthermore, the aggressiveness of breast cancer is related to GPER overexpression [163], and downregulation of this receptor was found to be associated with negative ER status, also suggesting a poor prognosis [164]. GPER-related cell proliferation was also associated with stimulation of the EGFR/ ERK/c-FOS/AP-1 signaling pathway, preventing cell cycle arrest and cell apoptosis in cancer-associated fibroblasts from BC patients [165]. A study by Li et al. [166] demonstrated the relationship between GPER and ERR $\alpha$ in SKBR3 cells, in which the expression of ERR $\alpha$ is dependent on GPER activation, and it was influenced by E2 or tamoxifen. Strengthening the major role of GPER in the proliferation of cancer cells, Zhou et al. [167] reported elevated levels of GPER in IDC than in normal breast tissues, and also showed apoptosis and proliferative processes to be regulated by GPER and estrogens. Cancer progression may also be related to aromatase expression. In this context, tamoxifen-induced aromatase expression was regulated by GPER in BC cells [168].

In a $\mathrm{BC}$ microenvironment, TAMs (especially the M2 phenotype) comprise a large part of the tumor mass, and constitute an important in situ source of E2 sufficient to stimulate epithelial cell proliferation and cytokine production. Moreover, monocytes and myeloid cell lines require differentiation into macrophages to express aromatase. In breast tissue macrophages, aromatase is positively correlated with the grade of lesion and E2 levels which results in rapid cell proliferation, an effect that is abolished by aromatase inhibitors [169].

\subsection{Endometrial cancer}

\subsubsection{Different subtypes and general aspects of sex hormone and steroid receptors}

Endometrial cancer (EC) is one of the most common gynecological diseases, and represents the fourth most common cancer in Europe and North America [170]. It is estimated that around 75\% of patients with EC are diagnosed in the early stages (International Federation of Gynecology and Obstetrics - FIGO - stages I or II), and a 5-year survival rate is approximately $74-91 \%$, whereas for women with advanced stage (stages III or IV), a 5-year overall survival decreases from 57-66\% to 20-26\%, respectively [155].

In general, ECs have been classified, on the basis of clinical, endocrine, and epidemiological observations, as type I or II, as defined by Bokhman [171]. Importantly, type I tumors are estrogen-dependent, and associated with endometrial hyperplasia; otherwise, type II tumors are estrogen-independent, and associated with endometrial atrophy. In addition, EC is also classified using histopathological aspects, such as subtypes of endometrioid carcinoma, serous carcinoma, carcinosarcoma, and clear-cell carcinomas [172]. Although still controversial, a number of correlations have been adopted between these subtypes and classification systems: Type I cancers generally exhibit endometrioid variants, and type II cancers are mostly serous carcinomas [173]. EC comprises a clinically, morphologically, and genetically heterogeneous types of tumors. These categories are limited in predicting effective response to therapy. In an effort to obtain potential targets for treatment in these subgroups of the disease, a genomic classification of EC has been developed [174].

According to Bokhman [171], ECs can be divided into two pathogenetic types based on clinical, metabolic, and endocrine features. Tumors described as type I are associated with excessive estrogen levels, obesity, and endometrial hyperplasia, being moderate or highly differentiated, whereas tumors described as type II are common in non-obese women, associated with no endocrine or metabolic disturbances, and presenting an atrophic endometrium, and poorly differentiated. The World Health Organization (WHO) classifies EC as epithelial carcinomas (serous, clear cell, endometrioid, mucinous, transitional cell, small cell, squamous cell, and undifferentiated), mixed epithelial and mesenchymal tumors (e.g. carcinosarcomas), and other malignant tumors [172].

Endometrioid carcinomas represent a range of neoplasms, varying from low to high grade, whereas serous and clear cell carcinomas exhibit aggressive phenotype and frequently develop in postmenopausal women in association with atrophic endometrium [172,175]. Notably, endometrioid type I are mostly related to genetic mutations in KRAS, PTEN, CTNNB1, and PIK3CA, whereas serous type II carcinomas exhibit HER2 amplification and recurrent TP53 mutations $[174,176]$. These findings are assumed to be consistent with the type I and type II division of ECs; thus, histological type and molecular features are key components of the dualistic Bokhman classification.

Important prognostic factors are relevant and may differ in patients with regard to the use of HRT and increased number of overweight or obese patients [177]. Furthermore, epidemiological data suggest obesity to be associated with type II EC, although to a lesser extent than type I ECs. The subtypes I and II are also linked to multiple risk factors such as diabetes, use of oral contraceptives, age at menarche, and smoking [177].

\subsubsection{Role of steroid receptors in EC}

There is no doubt that E2 plays an important role in the development of EC [178]. E2 and its analogues regulate the expression of selective estrogen responsive genes by binding to the cytoplasmic ER (Fig. 6), and after the complex migrates to the nucleus for transactivation of target genes [179]. Accumulating evidences have demonstrated an efficient and rapid signaling response to E2 that is independent of nuclear transactivation [180,181]. The subtype ER $\alpha$ is present on the cell membrane surface and activates a rapid E2-ER signaling (Fig. 6). Notably, a novel variant of ER $\alpha$ termed ER $\alpha 36$ has been identified, cloned and characterized [182]. Zou et al. [183] showed that ER $\alpha 36$ is expressed in both cell membrane and cytoplasm of Ishikawa cells (a human EC cell line). Conversely, ER $\alpha 66$ is predominantly localized to the nucleus [184].

Past studies pointed out that ER $\alpha 36$ mediates the initial effects of E2 signaling by activation of the MAPK pathway, thereby stimulating cell growth [185]. ER $\alpha 36$ is also capable of activating MAPK/ ERK signaling induced by antiestrogens, such as tamoxifen [185]. In addition, ER $\alpha 36$ activates downstream molecules through ERK and AKT signaling pathways [186]. Moreover, activations of PKA, PKC, AKT, and calcium channel are mediated by a rapid non-genomic effect of E2 to trigger a number of physiological cellular functions $[187,188]$. Most of these signaling pathways are related to the majority of cellular processes, including proliferation, differentiation, apoptosis, tumor progression, and aging.

The proteins ERK, JNK and P38 protein kinases are members of the large MAPK family related to cell growth and differentiation. An increasing body of evidence has reported the non-classical activation of the ERK1/2 by E2 in EC cells [189,190], and ERK1/2 can be alternatively activated by PKC [191]. In Ishikawa cells, E2 binds to ER $\alpha 36$ and activates the downstream MAPK/ERK pathway via PKC (Fig. 6). Many studies reported PKCd to efficiently act as a positive regulator of EC cell proliferation [192,193], and E2 binding to ER $\propto 36$ mediates the membrane-initiated PKCd signaling pathway. In general, the increased activity of PKCa is associated with higher capacity of migration and proliferation of cancer cells [194]. 


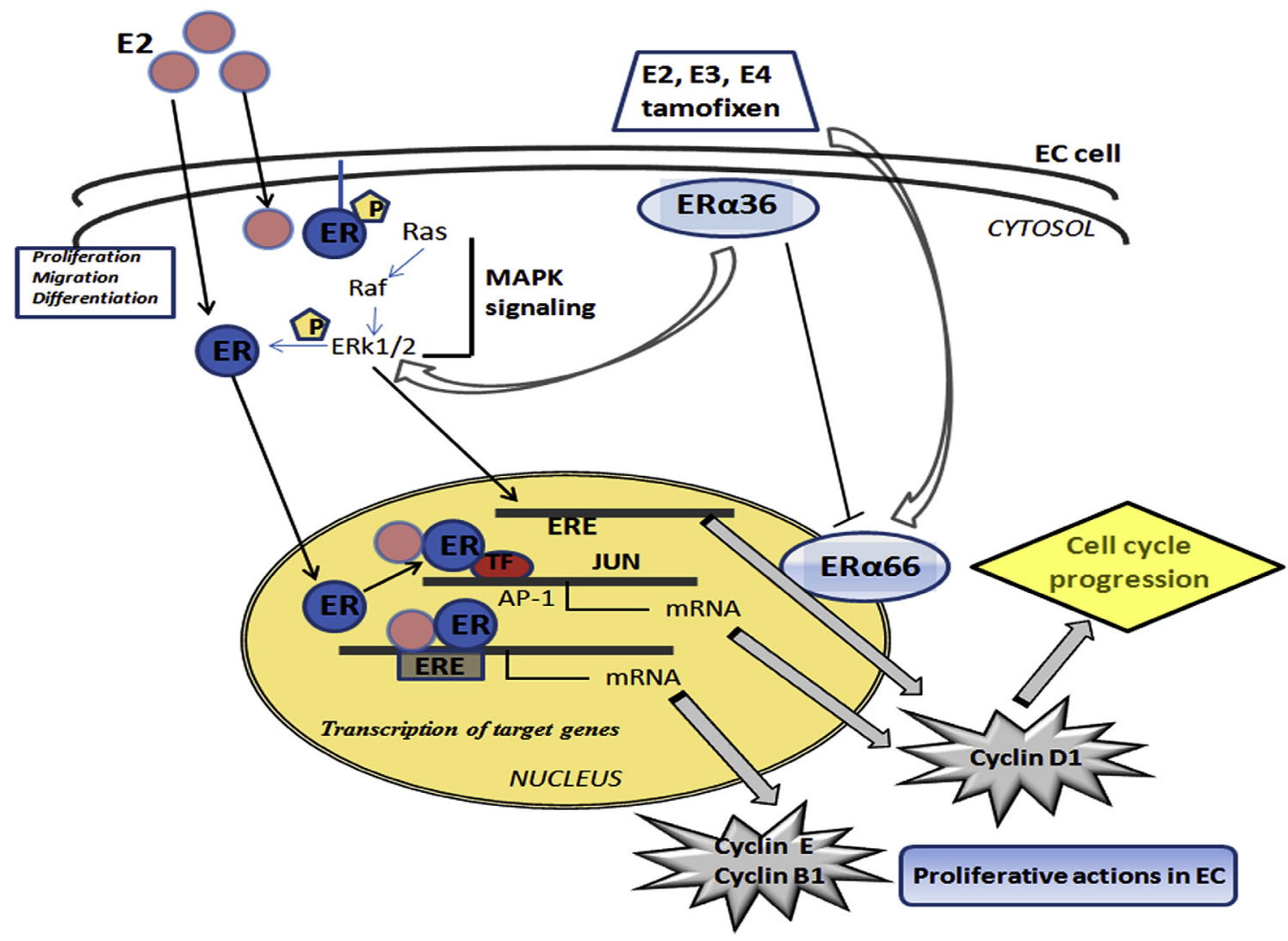

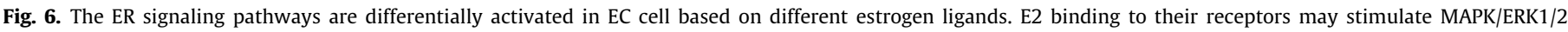

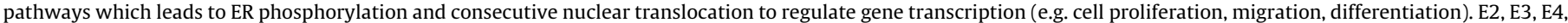

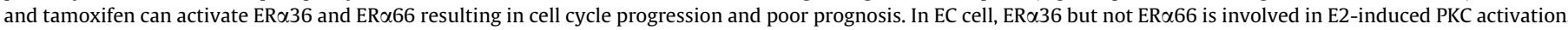

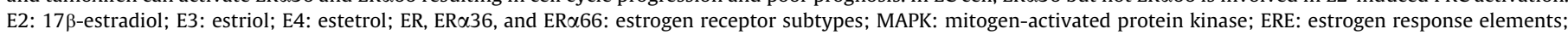
AP-1: activator protein-1; ERK1/2: extracellular signal-regulated protein kinases 1 and 2 .

For cell cycle progression, cyclin D1 is an essential element of the G1 phase which regulates cyclin dependent kinases (cdks). Cyclin D1/cdk complex is responsible for the phosphorylation cascade to regulate cell cycle [195]. It has been shown that cyclin D1 is associated with the pathogenesis of endometrial hyperplasia [196]. More recently, studies confirmed that the expression of cyclin D1 is upregulated by the MAPK/ERK and PKCd pathways [197]. In this regard, cyclin D1 seems to be expressed after ER $\alpha 36$-mediated E2 activation of the PKCd/ERK signaling pathway, thus resulting in cell cycle progression (Fig. 6). Importantly, Tong et al. [184] indicated that non-nuclear ER $\alpha 36$ is involved in the membrane E2 signaling pathways in Ishikawa cells, thus suggesting ER $\alpha 36$ as a novel pivotal player in EC.

Recently, TAM-secreted CXCL8 was severely associated with the downregulation of ER $\alpha$ expression in EC cells, which may lead to cancer cell invasion, migration, metastasis and poor outcomes [198]. This mechanism seems to be mediated by the transcription factor HOXB13, and reveals a promising alternative to explore new therapeutic opportunities for EC. In addition, low levels of P4 can lead to the inflammation associated with an increase in E2 production, thereby potentially stimulating the susceptibility to tumor initiation and progression [199]. Interestingly, the high activity of TAM was related to PR loss and malignant transformation in endometrioid adenocarcinoma.

\subsubsection{Major risk factors for EC}

There are a number of important risk factors related to EC (Fig. 7). Prolonged exposure to unopposed estrogen is mostly related to type I EC. HRT is indicated to control menopausal symptoms and can increase the risk of developing EC by 2- to 20 -fold, depending on the dose and time of use. Co-administration of progestins continuously or does not (from 10 to 15 days/month) dramatically reduce the increased risk of EC [200]. Furthermore, the high risk of developing endometrial hyperplasia and EC is linked to chronic anovulation (e.g. polycystic ovary syndrome), and to an increase in peripheral conversion of androgens into estrogens in adipose tissues. Also, tamoxifen acts as an estrogen antagonist in breast tissues and as an agonist in endometrial tissues. In fact, the use of tamoxifen is related to a 6 - to 8-fold increase in the risk of EC [201].

Obesity is another risk factor in the U.S., assumed to have a great impact on the incidence of EC [202]. The increased risk of EC associated with obesity is likely due to the higher E2 levels via aromatization. In addition, premenopausal and obese women are highly susceptible to develop chronic anovulation. Although there are some conflicting results, diabetes mellitus and hypertension might be related to the increased risk of EC [203]. Aging also represents a critical risk factor for the development of EC. Most women are late diagnosed at postmenopause [204], and younger women who develop EC are often more likely to be nulliparous and obese [205]. Reproductive aspects related to increased risk of EC include early age of menarche, late age of menopause, nulliparity, and infertility [206]. Notably, the use of oral contraceptives, such as medroxyprogesterone acetate, or even P4 secreting intrauterine devices significantly reduces the risk of developing EC [207].

Note that women with Lynch syndrome are at an increased risk of developing EC and OC. This disease is featured by a germline mutation in different mismatch repair systems: MLH1, MSH2, MSH6, or PMS2. For example, the cumulative risk of developing 


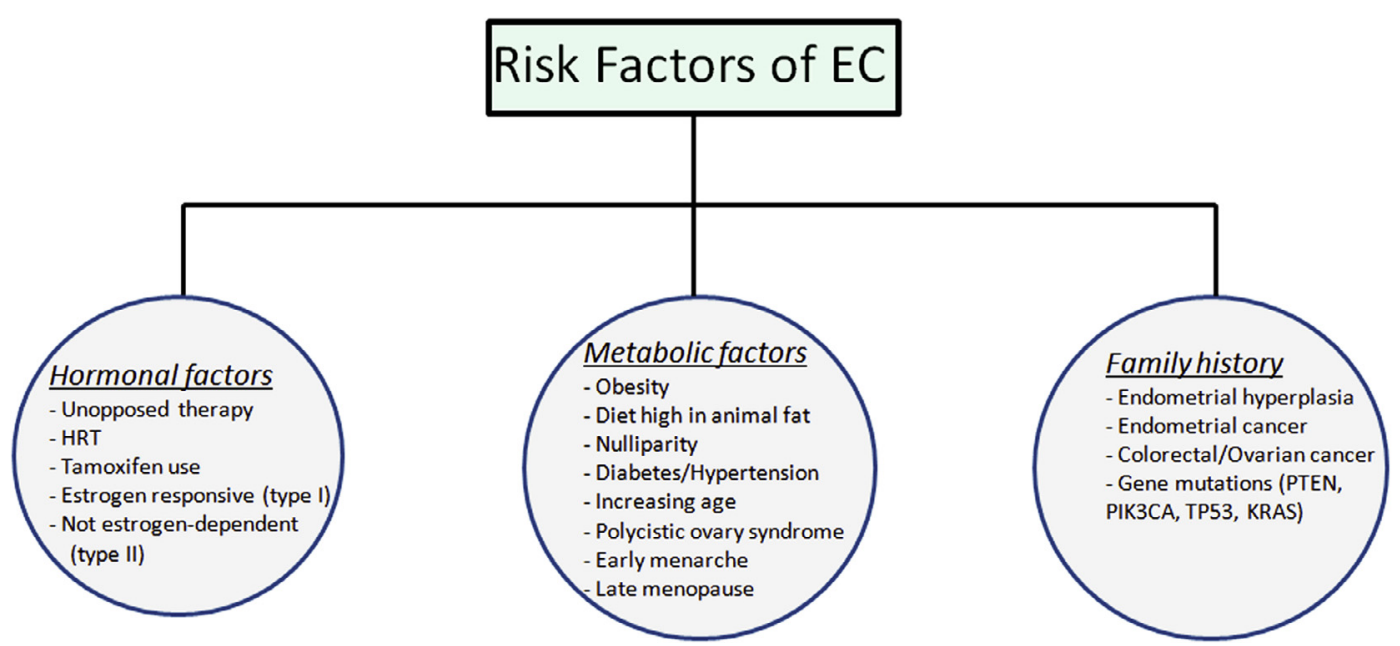

Fig. 7. Important risk factors associated with the development of EC.

EC by age is 54\% for MLH1, 21\% for MSH2, and 16\% for MSH6 [208]. Moreover, genetic mutations in the PTEN often occur in sporadic ECs [209]. Patients with Lynch syndrome have an increased frequency in germline PTEN mutation as they are at high risk for breast, and endometrial cancers [210]. Briefly, the genetic association between selective BRCA mutations and the risk of EC remains inconclusive [211].

\subsubsection{Endocrine therapy for EC}

A significant category of EC, particularly type I tumors that overexpress ER or PR, are thought to be good predictors of survival after endocrine therapy [212]. There are many important agents including selective estrogen receptor modulators (SERM), progestogens, aromatase and gonadotropins inhibitors which show relevant clinical benefits [213]. Regarding hormonal treatments, progestational agents revealed anti-tumor responses in $15 \%$ and $30 \%$ of patients [214]. Overall, progestogens have indicated good tolerability and efficacy with response rates around 22\% [215]. Positive PR receptor status has been shown to effectively correlate with treatment responsiveness [216]. Conversely, only a small number of PR-negative patients may benefit from treatment, thereby indicating the need to investigate more deeply the intrinsic mechanisms [207]. Approximately a 10\% overall response rate was observed in patients treated with aromatase inhibitors and tamoxifen $[217,218]$. In addition, the use of tamoxifen increased the response rate of $23 \%$ and $14 \%$ in patients with tumor grades I and II, respectively [217]. Although with no evident benefit, the therapeutic strategy of combining tamoxifen with megestrol promoted the upregulation of PR expression [219]. Mifepristone is a selective PR modulator that has been studied in PR-positive patients with relapsed EC but have achieved stable condition [220] with an overall response rate of $27 \%$ and a survival period of 14 months [219].

No improvements in survival rate of advanced EC have been reported with hormonal therapy [221]. Moreover, the quality of life of patients was insufficiently tested, and many of these studies were conducted using different methods and with various rates of hormone-receptor status, making it difficult to compare efficacy with more recent trials. Continuing efforts to clarify the role of HRT on clinical benefit, quality of life, and potential biomarkers of gynecological malignancies have been conducted, and a phase II trial is currently investigating the effect of anastrazole in women with hormone receptor-positive tumor recurrence (ANZGOG 0903) [222].
In parallel, fulvestrant, a high-affinity ER antagonist was studied in EC by two phase II trials [223,224], and only the first trial indicated an increased response rate in patients with PR-positive rather than ER-positive tumors (20\% and $16 \%$, respectively) [223]. The second study involving only patients with ER- or PR-positive tumors showed a partial response of $11.4 \%$. Only $40 \%$ of patients received the agent prior to chemotherapy [224]. Because EC can gradually develop mechanism(s) of drug chemoresistance or even reduce the expression of PRs or ERs, numerous trials have highlighted the potential of combining endocrine therapy with complementary targeting therapies [225].

The first in class oral steroid sulphatase (STS) inhibitor is termed BN83495 [226]. STS is a novel agent capable of inducing the transformation of biologically active steroids from inactive steroids. This is able to mediate the conversion of estrone sulfate and dehydroepiandrosterone sulfate into estrone and dehydroepiandrosterone, both with estrogenic actions that stimulate the growth of the endometrium [227]. A phase II trial has been conducted in EC comparing the efficacy of BN83495 with megestrol acetate in chemotherapy-naive patients [219].

\section{Concluding remarks}

It is currently assumed that low circulating sex steroids associated with the use of exogenous HRT found in postmenopausal women are one of the major risk factors for the development of reproductive cancers. In particular, the accurate interpretation and the assessment of menopausal status are determinant factors for planning the treatment strategies. There are a considerable number of new compounds mimicking the estrogen or progesterone effects in hormone-dependent tumors which rely on specific dose and time of stimulation. In reproductive cancers, most of these steroids bind to a specific receptor to mediate either classical or non-classical signaling pathways resulting in cell proliferation, survival, migration, metastasis, or even promoting apoptosis as a protective effect. More detailed studies emphasizing the specific actions of different sex hormones on the initiation and development of female reproductive cancers should be performed to guide appropriate hormone therapy and to standardize novel targets for adjuvant therapeutic interventions. Finally, future investigations on the sex hormone-receptor interface will bring new insights into the genetic, metabolic, and environmental factors to improve the quality of life and survival outcome in women. 


\section{Financial support}

We would like to thank to Fundação de Amparo à Pesquisa do Estado de São Paulo (FAPESP - Grant Nos. 2013/02466-7 and 2016/03993-9) for providing financial support.

\section{References}

[1] G.L. Hammond, Potential functions of plasma steroid-binding proteins, Trends Endocrinol. Metab. 6 (1995) 298-304.

[2] N. Fortunati, M.G. Catalano, G. Boccuzzi, R. Frairia, Sex Hormone-Binding Globulin (SHBG), estradiol and breast cancer, Mol. Cell. Endocrinol. 316 (2010) 86-92.

[3] W.Y. Chen, Exogenous and endogenous hormones and breast cancer, Best Pract. Res. Clin. Endocrinol. Metab. 22 (2008) 573-585.

[4] L.G. Chuffa, F.R. Seiva, W.J. Fávaro, J.P. Amorim, G.R. Teixeira, L.O. Mendes, et al., Melatonin and ethanol intake exert opposite effects on circulating estradiol and progesterone and differentially regulate sex steroid receptors in the ovaries, oviducts, and uteri of adult rats, Reprod. Toxicol. 39 (2013) 40-49.

[5] J. Matthews, J.A. Gustafsson, Estrogen signaling: a subtle balance between ER alpha and ER beta, Mol. Interv. 3 (2003) 281-292.

[6] M.H. Faulds, C. Zhao, K. Dahlman-Wright, J.A. Gustafsson, The diversity of sex steroid action: regulation of metabolism by estrogen signaling, J. Endocrinol. 212 (2012) 3-12.

[7] G. Bryzgalova, H. Gao, B. Ahren, J.R. Zierath, D. Galuska, T.L. Steiler, et al., Evidence that oestrogen receptor-alpha plays an important role in the regulation of glucose homeostasis in mice: insulin sensitivity in the liver, Diabetologia 49 (2006) 588-597.

[8] N. Heldring, A. Pike, S. Andersson, J. Matthews, G. Cheng, J. Hartman, et al., Estrogen receptors: how do they signal and what are their targets, Physiol. Rev. 87 (2007) 905-931.

[9] L.G. Chuffa, F.R. Seiva, W.J. Fávaro, G.R. Teixeira, J.P. Amorim, L.O. Mendes, et al., Melatonin reduces LH, 17 beta-estradiol and induces differential regulation of sex steroid receptors in reproductive tissues during rat ovulation, Reprod. Biol. Endocrinol. 9 (2011) 108.

[10] R.D. Brinton, R.F. Thompson, M.R. Foy, M. Baudry, J. Wang, C.E. Finch, et al., Progesterone receptors: form and function in brain, Front. Neuroendocrinol. 29 (2008) 313-339.

[11] O.M. Conneely, J.P. Lydon, Progesterone receptors in reproduction: functional impact of the A and B isoforms, Steroids 65 (2000) 571-577.

[12] S.Y. Jeon, K.A. Hwang, K.C. Choi, Effect of steroid hormones, estrogen and progesterone, on epithelial mesenchymal transition in ovarian cancer development, J. Steroid Biochem. Mol. Biol. 158 (2016) 1-8.

[13] J.A. Simental, M. Sar, M.V. Lane, F.S. French, E.M. Wilson, Transcriptional activation and nuclear targeting signals of the human androgen receptor, J. Biol. Chem. 266 (1991) 510-518.

[14] W.H. Walker, Non-classical actions of testosterone and spermatogenesis, Philos. Trans. R. Soc. Lond. B Biol. Sci. 365 (2010) 1557-1569.

[15] M. Shihan, K.H. Chan, L. Konrad, G. Scheiner-Bobis, Non-classical testosterone signaling in spermatogenic GC-2 cells is mediated through ZIP9 interacting with Gna11, Cell. Signal. 27 (2015) 2077-2086.

[16] C. Dambaki, C. Kogia, M. Kampa, K. Darivianaki, M. Nomikos, P. Anezinis, et al., Membrane testosterone binding sites in prostate carcinoma as a potential new marker and therapeutic target: study in paraffin tissue sections, BMC Cancer 5 (2005) 148.

[17] F. Rahman, H.C. Christian, Non-classical actions of testosterone: an update, Trends Endocrinol. Metab. 18 (2007) 371-378.

[18] R. Fu, J. Liu, J. Fan, R. Li, D. Li, J. Yin, et al., Novel evidence that testosterone promotes cell proliferation and differentiation via $G$ protein-coupled receptors in the rat L6 skeletal muscle myoblast cell line, J. Cell. Physiol. 227 (2012) 98-107.

[19] E. Folkerd, M. Dowsett, Sex hormones and breast cancer risk and prognosis, Breast 22 (2013) S38-S43.

[20] E.R. Simpson, M.S. Mahendroo, G.D. Means, M.W. Kilgore, C.J. Corbin, C.R. Mendelson, Tissue-specific promotors regulate aromatase cytochrome P450 expression, J. Steroid Biochem. Mol. Biol. 44 (1993) 321-330.

[21] S.E. Hankinson, J.E. Manson, D. Spiegelman, W.C. Willett, C. Longcope, F.E. Speizer, Reproducibility of plasma hormone levels in postmenopausal women over a 2-3 year period, Cancer Epidemiol. Biomarkers Prev. 4 (1995) 649-654.

[22] R.A. Lobo, Androgens in postmenopausal women: production, possible role, and replacement options, Obstet. Gynecol. Surv. 56 (2001) 361-376.

[23] R.B. Greenblatt, Androgenic therapy in women, J. Clin. Endocrinol. Metab. 2 (1942) 2665-2666.

[24] I.D. Burd, G.A. Bachmann, Androgen replacement in menopause, Curr. Womens Health. Rep. 1 (2001) 202-205.

[25] R.M. Tamimi, S.E. Hankinson, W.Y. Chen, B. Rosner, G.A. Colditz, Combined estrogen and testosterone use and risk of breast cancer in postmenopausal women, Arch. Intern. Med. 166 (2006) 1483-1489.

[26] P.G. Morris, C.A. Hudis, D. Giri, M. Morrow, D.J. Falcone, X.K. Zhou, et al., Inflammation and increased aromatase expression occur in the breast tissue of obese women with breast cancer, Cancer Prev. Res. (Phila) 4 (2011) 1021 1029 .
[27] X. Wang, M.M. Docanto, H. SasanoKConFab, C. Lo, E.R. Simpson, K.A. Brown, Prostaglandin E2 inhibits p53 in human breast adipose stromal cells: a novel mechanism for the regulation of aromatase in obesity and breast cancer, Cancer Res. 75 (2015) 645-655.

[28] C.C. Au, M.M. Docanto, H. Zahid, F.M. Raffaelli, R.L. Ferrero, J.B. Furness, et al., Des-acyl ghrelin inhibits the capacity of macrophages to stimulate the expression of aromatase in breast adipose stromal cells, J. Steroid Biochem. Mol. Biol. (2016), http://dx.doi.org/10.1016/j.jsbmb.2016.07.005 [Epub ahead of print].

[29] L.G. Chuffa, M.S. Alves, M. Martinez, I.C. Camargo, P.F.F. Pinheiro, R.F. Domeniconi, et al., Apoptosis is triggered by melatonin in an in vivo mode of ovarian carcinoma, Endocr. Relat. Cancer 23 (2016) 65-76.

[30] J. Prat, Ovarian carcinomas: five distinct diseases with different origins, genetic alterations, and clinicopathological features, Virchows Arch. 460 (2012) 237-249.

[31] K.K. Tsilidis, N.E. Allen, T.J. Key, L. Dossus, A. Lukanova, K. Bakken, et al., Oral contraceptive use and reproductive factors and risk of ovarian cancer in the European Prospective Investigation into Cancer and Nutrition, Br. J. Cancer 105 (2011) 1436-1442.

[32] J. Ose, R.T. Fortner, S. Rinaldi, H. Schock, K. Overvad, A. Tjonneland, et al, Endogenous androgens and risk of epithelial invasive ovarian cancer by tumor characteristics in the European Prospective Investigation into Cancer and Nutrition. Int. J. Cancer 136 (2015) 399-410.

[33] K.J. Helzlsouer, A.J. Alberg, G.B. Gordon, C. Longcope, T.L. Bush, S.C. Hoffman, et al., Serum gonadotropins and steroid hormones and the development of ovarian cancer, JAMA 274 (1995) 1926-1930.

[34] L. Speroff, A.F. Marc, Regulation of the menstrual cycle, in: A.F. Speroff (Ed.) Clinical Gynecologic Endocrinology and Infertility, 2005, pp. 187-231. Baltimore.

[35] H. Schock, H.M. Surcel, A. Zeleniuch-Jacquotte, K. Grankvist, H.A. Lakso, R.T. Fortner, Early pregnancy sex steroids and maternal risk of epithelial ovarian cancer, Endocr. Relat. Cancer 21 (2014) 831-844.

[36] P.H. Wang, C. Chang, Androgens and ovarian cancers, Eur. J. Gynaecol. Oncol. 25 (2004) 157-163.

[37] P.L. Horn-Ross, A.S. Whittemore, R. Harris, J. Itnyre, Characteristics relating to ovarian cancer risk: collaborative analysis of 12 U.S. case-control studies. VI. Non-epithelial cancers among adults. Collaborative Ovarian Cancer Group, Epidemiology 3 (1992) 490-495.

[38] D. Pectasides, E. Pectasides, D. Kassanos, Germ cell tumors of the ovary, Cancer Treat Ver. 34 (2008) 427-441.

[39] L. Lee-Jones, Ovary: germ cell tumors. Atlas Genet. Cytogenet. Oncol Haematol. OvarianGermCelliD5067.html> (accessed 01.09.2016).

[40] T. Chen, H.M. Surcel, E. Lundin, M. Kaasila, H.A. Lakso, H. Schock, et al., Circulating sex steroids during pregnancy and maternal risk of non-epithelial ovarian cancer, Cancer Epidemiol. Biomarkers Prev. 20 (2011) 324-336.

[41] R.H. Young, R.E. Scully, Sex cord-stromalsteroid cell and other ovarian tumors, in: Blaustein's Pathology of the Femal Genital Tract, fourth ed., Springer-Verlag, New York, 1994, pp. 818-824.

[42] M.B. Reedy, W.E. Richards, F. Ueland, K. Uy, E.Y. Lee, C. Bryant, C., et al., Ovarian steroid cell tumors, not otherwise specified: a case report and literature review, Gynecol. Oncol. 75 (1999) 293-297.

[43] M. Mizoguchi, S. Minami, M. Yamamoto, Y. Tanizaki, A. Kobayashi, K. Ino Ovarian steroid cell tumor, not otherwise specified, producing testosterone, J. Obstet. Gynaecol. Res. 40 (2014) 2081-2085.

[44] T. Rutherford, W.D. Brown, E. Sapi, S. Aschkenazi, A. Munoz, G. Mor, Absence of estrogen receptor-beta expression in metastatic ovarian cancer, Obstet. Gynecol. 96 (2000) 417-421.

[45] W. Sieh, M. Kobel, T.A. Longacre, D.D. Bowtell, A. deFazio, M.T. Goodman, et al., Hormone-receptor expression and ovarian cancer survival: an ovarian tumor tissue analysis consortium study, Lancet Oncol. 14 (2013) $853-862$.

[46] M. van Kruchten, P.W. van der Marel, H.J.G. Arts, H. Hollema, L. Munck, T. van der Sluis, et al., Frequency and prognostic value of hormone receptor expression in epithelial ovarian cancer, Cancer Res. 73 (2013) 4768.

[47] A. Ciucci, G.F. Zannoni, M. Buttarelli, L. Lisi, D. Travaglia, E. Martinelli, et al. Multiple direct and indirect mechanisms drive estrogen-induced tumor growth in high grade serous ovarian cancers, Oncotarget 7 (2016) 81558171.

[48] X. Lv, C. Wang, G-1: new potential therapeutic option for ovarian cancer Cancer Cell Microenviron. 1 (2014) e27, http://dx.doi.org/10.14800/ccm.27.

[49] W. Bai, B. Oliveros-Saunders, Q. Wang, M.E. Acevedo-Duncan, S.V. Nicosia, Estrogen stimulation of ovarian surface epithelial cell proliferation, In Vitro Cell Dev. Biol. Anim. 36 (2000) 657-666.

[50] K.C. Choi, S.K. Kang, C.J. Tai, N. Auersperg, P.C. Leung, Estradiol up-regulates antiapoptotic Bcl-2 messenger ribonucleic acid and protein in tumorigenic ovarian surface epithelium cells, Endocrinology 142 (2001) 2351-2360.

[51] S. Mabuchi, M. Ohmichi, A. Kimura, Y. Nishio, E. Arimoto-Ishida, N. YadaHashimoto, et al., Estrogen inhibits paclitaxel-induced apoptosis via the phosphorylation of apoptosis signal-regulating kinase 1 in human ovarian cancer cell lines, Endocrinology 145 (2004) 49-58.

[52] L. Rosano, F. Spinella, V. Di Castro, M.R. Nicotra, S. Dedhar, A.G. de Herreros, P. G. Natali, et al., Endothelin-1 promotes epithelial-to-mesenchymal transition in human ovarian cancer cells, Cancer Res. 65 (2005) 11649-11657.

[53] G.G. Chen, Q. Zeng, G.M. Tse, Estrogen and its receptors in cancer, Med. Res. Rev. 28 (2008) 954-974. 
[54] K.K. Chan, N. Wei, S.S. Liu, L. Xiao-Yun, A.N. Cheung, H.Y. Ngan, Estrogen receptor subtypes in ovarian cancer: a clinical correlation, Obstet. Gynecol. 111 (2008) 144-151.

[55] D. Zhao, F. Zhang, W. Zhang, J. He, Y. Zhao, J. Sun, Prognostic role of hormone receptors in ovarian cancer: a systematic review and meta-analysis, Int. J. Gynecol. Cancer 23 (2013) 25-33.

[56] F. Modugno, R. Laskey, A.L. Smith, C.L. Andersen, P. Haluska, S. Oesterreich, Hormone response in ovarian cancer: time to reconsider as a clinical target?, Endocr Relat. Cancer 19 (2012) R255-R279.

[57] C.H. Diep, N.J. Charles, C.B. Gilks, S.E. Kalloger, P.A. Argenta, C.A. Lange, Progesterone receptors induce FOXO1-dependent senescence in ovarian cancer cells, Cell Cycle 12 (2013) 1433-1449.

[58] C.H. Diep, A.R. Daniel, L.J. Mauro, T.P. Knutson, C.A. Lange, Progesterone action in breast, uterine, and ovarian cancers, J. Mol. Endocrinol. 54 (2015) R31-R53.

[59] J. Escobar, A.C. Klimowicz, M. Dean, P. Chu, J.G. Nation, G.S. Nelson, et al., Quantification of ER/PR expression in ovarian low-grade serous carcinoma, Gynecol. Oncol. 128 (2013) 371-376.

[60] Early Breast Cancer Trialists' Collaborative GroupTamoxifen for early breast cancer: an overview of the randomised trials, Lancet 351 (1998) 1451-1467.

[61] J.E. Rossouw, G.L. Anderson, R.L. Prentice, A.Z. LaCroix, C. Kooperberg, M.L. Stefanick, et al., Risks and benefits of estrogen plus progestin in healthy postmenopausal women: principal results from the women's health initiative randomized controlled trial, JAMA 288 (2002) 321-333.

[62] Collaborative Group on Epidemiological Studies of Ovarian Cancer, V. Beral, K. Gaitskell, C. Hermon, K. Moser, G. Reeves, et al., Menopausal hormone use and ovarian cancer risk: individual participant meta-analysis of 52 epidemiological studies, Lancet 385 (2015) 1835-1842.

[63] C.M. Greiser, E.M. Greiser, M. Doren, Menopausal hormone therapy and risk of ovarian cancer: systematic review and meta-analysis, Hum. Reprod. Update 13 (2007) 453-463.

[64] M.A. Rossing, K.L. Cushing-Haugen, K.G. Wicklund, J.A. Doherty, N.S. Weiss, Menopausal hormone therapy and risk of epithelial ovarian cancer, Cancer Epidemiol. Biomarkers Prev. 16 (2007) 2548-2556.

[65] R.J. Santen, D.C. Allred, S.P. Ardoin, D.F. Archer, N. Boyd, et al., Postmenopausal hormone therapy: an Endocrine Society scientific statement, J. Clin. Endocrinol. Met. 95 (2010) s1-s66.

[66] C.L. Pearce, K. Chung, M.C. Pike, A.H. Wu, Increased ovarian cancer risk associated with menopausal estrogen therapy is reduced by adding a progestin, Cancer 115 (2009) 531-539.

[67] V. Beral, D. Bull, J. Green, G. Reeves, Ovarian cancer and hormone replacement therapy in the Million Women Study, Lancet 369 (2007) 1703-1710.

[68] L.S. Morch, E. Lokkegaard, A.H. Andreasen, S. Kruger-Kjaer, O. Lidegaard, Hormone therapy and ovarian cancer, JAMA 302 (2009) 298-305.

[69] B. Trabert, N. Wentzensen, H.P. Yang, M.E. Sherman, A. Hollenbeck, K.N Danforth, et al., Ovarian cancer and menopausal hormone therapy in the NIHAARP diet and health study, Br. J. Cancer 107 (2012) 1181-1187.

[70] L.S. Morch, E. Lokkegaard, A.H. Andreasen, S.K. Kjaer, O. Lidegaard, Hormone therapy and different ovarian cancers: a National Cohort study, Am. J Epidemiol. 175 (2012) 1234-1242.

[71] American Cancer Society, 2016 <http://www.cancer.org/cancer/ ovariancancer/detailedguide/ovarian-cancer-key-statistics> (accessed 01.09.2016).

[72] M. Stasenko, M. Plegue, A.P. Sciallis, K. McLean, Clinical response to antiestrogen therapy in platinum-resistant ovarian cancer patients and the role of tumor estrogen receptor expression status, Int. J002E Gynecol. Cancer 25 (2015) 222-228.

[73] J.T. Thigpen, J.A. Blessing, P.J. DiSaia, E. Yordan, L.F. Carson, C. Evers, A randomized comparison of doxorubicin alone versus doxorubicin plus cyclophosphamide in the management of advanced or recurrent endometrial carcinoma: a Gynecologic Oncology Group study, J. Clin. Oncol. 12 (1994) 1408-1414.

[74] S.A. Cannistra, Cancer of the ovary, N. Engl. J. Med. 351 (2004) 2519-2529.

[75] D. Lorusso, A. Di Stefano, F. Fanfani, L. Marini, V. Adamo, G. Scambia, Role of gemcitabine in ovarian cancer treatment, Ann. Oncol. 17 (2006) 188-194.

[76] P.A. Argenta, I. Um, C. Kay, D. Harrison, D. Faratian, T. Sueblinvong, et al., Predicting response to the anti-estrogen fulvestrant in recurrent ovarian cancer, Gynecol. Oncol. 131 (2013) 368-373.

[77] Y. Yokoyama, H. Mizunuma, Recurrent epithelial ovarian cancer and hormone therapy, World J. Clin. Cases 1 (2013) 187-190.

[78] H. Karagol, P. Saip, K. Uygun, M. Caloglu, Y. Eralp, F. Tas, et al., The efficacy of tamoxifen in patients with advanced epithelial ovarian cancer, Med. Oncol. 24 (2007) 39-43.

[79] S. Cariou, J.C.H. Donovan, W.M. Flanagan, A. Milic, N. Bhattacharya, J.M Slingerland, Down-regulation of p21WAF1/CIP1 or p27Kip1 abrogates antiestrogen-mediated cell cycle arrest in human breast cancer cells, Proc. Natl. Acad. Sci. U.S.A. 97 (2000) 9042-9046.

[80] J.Y. Lee, J.Y. Shin, H.S. Kim, J.I. Heo, Y.J. Kho, H.J. Kang, et al., Effect of combined treatment with progesterone and tamoxifen on the growth and apoptosis of human ovarian cancer cells, Oncol. Rep. 27 (2012) 87-93.

[81] F. Simpkins, P. Hevia-Paez, J. Sun, W. Ullmer, C.A. Gilbert, T. da Silva, et al., Src Inhibition with saracatinib reverses fulvestrant resistance in ER-positive ovarian cancer models in vitro and in vivo, Clin. Cancer Res. 18 (2012) 5911 5923.

[82] P.A. Argenta, S.G. Thomas, P.L. Judson, L.S. Jr Downs, M.A. Geller, L.F. Carson, et al., A phase II study of fulvestrant in the treatment of multiply-recurrent epithelial ovarian cancer, Gynecol. Oncol. 113 (2009) 205-209.
[83] J.R. Wiener, T.C. Windham, V.C. Estrella, N.U. Parikh, P.F. Thall, M.T. Deavers, et al., Activated SRC protein tyrosine kinase is overexpressed in late-stage human ovarian cancers, Gynecol. Oncol. 88 (2003) 73-79.

[84] X.F. Le, R.C. Jr Bast, Src family kinases and paclitaxel sensitivity, Cancer Biol. Ther. 12 (2011) 260-269.

[85] S. Cunat, F. Rabenoelina, J.P. Daures, D. Katsaros, H. Sasano, W.R. Miller, et al., Aromatase expression in ovarian epithelial cancers, J. Steroid Biochem. Mol. Biol. 93 (2005) 15-24.

[86] F. Simpkins, A. Garcia-Soto, J. Slingerland, New insights on the role of hormonal therapy in ovarian cancer, Steroids 78 (2013) 530-537.

[87] F. Labrie, A. Belanger, J. Simard, L. Van, C. Labrie, DHEA and peripheral androgen and estrogen formation: intracinology, Ann. N. Y. Acad. Sci. 774 (1995) 16-28.

[88] B.J. Slotman, R. Kuhnel, B.R. Rao, G.H. Dijkhuizen, G.J. De, J.G. Stolk, Importance of steroid receptors and aromatase activity in the prognosis of ovarian cancer: high tumor progesterone receptor levels correlate with longer survival, Gynecol. Oncol. 33 (1989) 76-81.

[89] J. Kitawaki, T. Noguchi, T. Yamamoto, K. Yokota, K. Maeda, M. Urabe, et al., Immunohistochemical localisation of aromatase and its correlation with progesterone receptors in ovarian epithelial tumours, Anticancer Res. 16 (1996) 91-97.

[90] Z.W. Wong, M.J. Ellis, First-line endocrine treatment of breast cancer: aromatase inhibitor or antioestrogen?. Br J. Cancer 90 (2004) 20-25.

[91] H. Hirakawa, Y. Yokoyama, H. Yoshida, H. Mizunuma, Inhibitory effects of aromatase inhibitor on estrogen receptor-alpha positive ovarian cancer in mice, J Ovarian Res. 7 (2014) 4.

[92] J.J. Kavanagh, W. Hu, S. Fu, M. Deavers, C. Moore, R.L. Coleman, et al., Antitumor activity of letrozole in patients with recurrent advanced low malignant potential or low-grade serous ovarian tumors, J. Clin. Oncol. 25 (2007) 5582.

[93] J.F. Smyth, C. Gourley, G. Walker, M.J. MacKean, A. Stevenson, A.R. Williams, et al., Antiestrogen therapy is active in selected ovarian cancer cases: the use of letrozole in estrogen receptor-positive patients, Clin. Cancer Res. 13 (2007) 3617-3622.

[94] S.P. Langdon, G.L. Hirst, E.P. Miller, R.A. Hawkins, A.L. Tesdale, J.F. Smyth, et al., The regulation of growth and protein expression by estrogen in vitro: a study of 8 human ovarian carcinoma cell lines, J. Steroid Biochem. Mol. Biol. 50 (1994) 131-135.

[95] S.P. Langdon, A.J. Crew, A.A. Ritchie, M. Muir, A. Wakeling, J.F. Smyth, et al., Growth inhibition of oestrogen receptor-positive human ovarian carcinoma by anti-oestrogens in vitro and in a xenograft model, Eur. J. Cancer 30 (1994) 682-686.

[96] G.N. Armaiz-Pena, L.S. Mangala, W.A. Spannuth, Y.G. Lin, N.B. Jennings, A.M. Nick, et al., Estrous cycle modulates ovarian carcinoma growth, Clin. Cancer Res. 15 (2009) 2971-2978.

[97] A. Bardin, P. Hoffmann, N. Boulle, D. Katsaros, F. Vignon, P. Pujol, et al., Involvement of estrogen receptor beta in ovarian carcinogenesis, Cancer Res. 64 (2004) 5861-5869.

[98] K.K.L. Chan, T.H.Y. Leung, D.W. Chan, N. Wei, G.T.Y. Lau, S.S. Liu, et al., Targeting estrogen receptor subtypes (ERa and ERb) with selective ER modulators in ovarian cancer, J. Endocrinol. 221 (2014) 325-336.

[99] E.O. Fourkala, O. Blyuss, H. Field, R. Gunu, A. Ryan, J. Barth, et al., Sex hormone measurements using mass spectrometry and sensitive extraction radioimmunoassay and risk of estrogen receptor negative and positive breast cancer: case control study in UK Collaborative Cancer Trial of Ovarian Cancer Screening (UKCTOCS), Steroids 110 (2016) 62-69.

[100] Y. Omoto, H. Iwase, Clinical significance of estrogen receptor $\beta$ in breast and prostate cancer from biological aspects, Cancer Sci. 106 (2015) 337-343.

[101] U. Veronesi, A. Goldhirsch, P. Boyle, R. Orecchia, G. Viale, Breast cancer, Discov. Med. 5 (2005) 271-277.

[102] Collaborative Group on Hormonal Factors in Breast CancerMenarche, menopause, and breast cancer risk: individual participant meta-analysis, including 118.964 women with breast cancer from 117 epidemiological studies, Lancet Oncol. 13 (2012) 1141-1151.

[103] M.D. Althuis, J.H. Fergenbaum, M. Garcia-Closas, L.A. Brinton, M.P. Madigan, M.E. Sherman, Etiology of hormone receptor-defined breast cancer: a systematic review of the literature, Cancer Epidemiol. Biomarkers Prev. 13 (2004) 1558-1568.

[104] E.O. Fourkala, A. Zaikin, M. Burnell, A. Gentry-Maharaj, J. Ford, R. Gunu, et al., Association of serum sex steroid receptor bioactivity and sex steroid hormones, Endocr. Relat. Cancer 19 (2012) 137-147.

[105] S. Hiscox, L. Morgan, D. Barrow, C. Dutkowskil, A. Wakeling, R.I. Nicholson, Tamoxifen resistance in breast cancer cells is accompanied by an enhanced motile and invasive phenotype: inhibition by gefitinib ('Iressa', ZD1839), Clin. Exp. Metastasis 21 (2004) 201-212.

[106] S.F. Doisneau-Sixou, C.M. Sergio, J.S. Carroll, R. Hui, E.A. Musgrove, R.L. Sutherland, Estrogen and antiestrogen regulation of cell cycle progression in breast cancer cells, Endocr. Relat. Cancer 10 (2003) 179-186.

[107] D. Jacenik, A.I. Cygankiewicz, W.M. Krajewska, The G protein-coupled estrogen receptor as a modulator of neoplastic transformation, Mol. Cell. Endocrinol. 429 (2016) 10-18.

[108] J. Liu, Z. Xu, X. Ma, B. Huang, X. Pan, Role of ER- $\alpha 36$ in breast cancer by typical xenoestrogens, Tumor Biol. 36 (2015) 7355-7364.

[109] M. Warner, S. Saji, J.A. Gustafsson, The normal and malignant mammary gland: a fresh look with ER beta onboard, J. Mammary Gland Biol. Neoplasia 5 (2004) 289-294. 
[110] R.J. Cossetti, K.A. Gelmon, Strategies to overcome resistance to hormonal therapy, Breast Dis. 25 (2014) 117-119.

[111] Z.Y. Wang, L. Yin, Estrogen receptor alpha-36 (ER-a36): a new player in human breast cancer, Mol. Cell. Endocrinol. 418 (2015) 193-206.

[112] X. Zhang, L. Kang, L. Ding, S. Vranic, Z. Gatalica, Z.Y.A. Wang, Positive feedback loop of ER- $\alpha 36 /$ EGFR promotes malignant growth of ER-negative breast cancer cells, Oncogene 30 (2010) 770-780.

[113] L. Shi, B. Dong, Z. Li, Y. Lu, T. Ouyang, J. Li, et al., Expression of ER- $\alpha 36$, a novel variant of estrogen receptor $\alpha$, and resistance to tamoxifen treatment in breast cancer, J. Clin. Oncol. 27 (2009) 3423-3429.

[114] B. Huang, M. Warner, J.Å. Gustafsson, Estrogen receptors in breast carcinogenesis and endocrine therapy, Mol. Cell. Endocrinol. 418 (2015) 240-244.

[115] G. Rajapaksa, C. Thomas, J.A. Gustafsson, Estrogen signaling and unfolded protein response in breast cancer, J. Steroid Biochem. Mol. Biol. (2016), http://dx.doi.org/10.1016/j.jsbmb.2016.03.036. Epub ahed of print.

[116] J. Zhang, G. Li, Z. Li, X. Yu, Y. Zheng, K. Jin, et al., Estrogen-independent effects of ER- $\alpha 36$ in ER-negative breast cancer, Steroids 77 (2012) 666-673.

[117] C. Marquette, L. Nabell, Chemotherapy-Resistant Metastatic Breast Cancer, Curr. Treat. Options Oncol. 13 (2012) 263-275.

[118] Early Breast Cancer Trialists' Collaborative Group, C. Davies, J. Godwin, R. Gray, M. Clarke, D. Cutter, et al., Relevance of breast cancer hormone receptors and other factors to the efficacy of adjuvant tamoxifen: patientlevel metaanalysis of randomised trials, Lancet 378 (2011) 771-784.

[119] P. Walter, S. Green, G. Greene, A. Krust, J.M. Bornert, J.M. Jeltsch, et al., Cloning of the human estrogen receptor cDNA, Proc. Natl. Acad. Sci. U.S.A. 82 (1985) 7889-7893.

[120] D.C. Allred, Issues and updates: evaluating estrogen receptor-alpha, progesterone receptor, and HER2 in breast cancer, Mod. Pathol. 23 (2010) S52-S59.

[121] W. Yue, J.D. Yager, J.P. Wang, E.R. Jupe, R.J. Santen, Estrogen receptordependent and independent mechanisms of breast cancer carcinogenesis, Steroids 78 (2013) 161-170.

[122] H.J. Burstein, S. Temin, H. Anderson, T.A. Buchholz, N.E. Davidson, K.E. Gelmon, et al., Adjuvant endocrine therapy for women with hormone receptor-positive breast cancer: American society of clinical oncology clinical practice guideline focused update, J. Clin. Oncol. 32 (2014) 22552269.

[123] F. Holst, Estrogen receptor alpha gene amplification in breast cancer: 25 years of debate, World J. Clin. Oncol. 7 (2016) 160-173.

[124] B.J. Long, S.L. Tilghman, W. Yue, A. Thiantanawat, D.N. Grigoryev, A.M. Brodie, The steroidal antiestrogen ICI 182,780 is an inhibitor of cellular aromatase activity, J. Steroid Biochem. Mol. Biol. 67 (1998) 293-304.

[125] A. Hurtado, K.A. Holmes, C.S. Ross-Innes, D. Schmidt, J.S. Carroll, FOXA1 is a key determinant of estrogen receptor function and endocrine response, Nat. Genet. 43 (2011) 27-33.

[126] L. Magnani, E.B. Ballantyne, X. Zhang, M. Lupien, PBX1 genomic pioneer function drives ERalpha signaling underlying progression in breast cancer, PLoS Genet. 7 (2011), http://dx.doi.org/10.1371/journal.pgen.1002368. e1002368.

[127] S.K. Tan, Z.H. Lin, C.W. Chang, V. Varang, K.R. Chng, Y.F. Pan, et al., AP2gamma regulates oestrogen receptor-mediated long-range chromatin interaction and gene transcription, EMBO J. 30 (2011) 2569-2581.

[128] K.D. Flach, W. Zwart, The first decade of estrogen receptor cistromics in breast cancer, J. Endocrinol. 229 (2016) R43-R56.

[129] A.K. Shiau, D. Barstad, P.M. Loria, L. Cheng, P.J. Kushner, D.A. Agard, et al., The structural basis of estrogen receptor/ coactivator recognition and the antagonism of this interaction by tamoxifen, Cell 95 (1998) 927-937.

[130] K. Chia, M. O’Brien, M. Brown, E. Lim, Targeting the androgen receptor in breast cancer, Curr. Oncol. Rep. 17 (2015) 4.

[131] L.A. Niemeier, D.J. Dabbs, S. Beriwal, J.M. Striebel, R. Bhargava, Androgen receptor in breast cancer: expression in estrogen receptor-positive tumors and in estrogen receptor-negative tumors with apocrine differentiation, Mod. Pathol. 23 (2010) 205-212.

[132] Y. Tsutsumi, Apocrine carcinoma as triple-negative breast cancer: novel definition of apocrine-type carcinoma as estrogen/progesterone receptornegative and androgen receptor-positive invasive ductal carcinoma, Jpn. J. Clin. Oncol. 42 (2012) 375-386.

[133] I. Castellano, E. Allia, V. Accortanzo, A.M. Vandone, L. Chiusa, R. Arisio, et al., Androgen receptor expression is a significant prognostic factor in estrogen receptor positive breast cancers, Breast Cancer Res. Treat. 124 (2010) 607617.

[134] D.R. Cochrane, S. Bernales, B.M. Jacobsen, D.M. Cittelly, E.N. Howe, N.C. D'Amato, et al., Role of the androgen receptor in breast cancer and preclinical analysis of enzalutamide, Breast Cancer Res. 16 (2014) R7.

[135] N.C. D’Amato, M.A. Gordon, B. Babbs, N.S. Spoelstra, K.T. Carson Butterfield, K. C. Torkko, et al., Cooperative dynamics of AR and ER activity in breast cancer, Mol. Cancer Res. 14 (2016) 1054-1067.

[136] C.K. Osborne, R. Schiff, Mechanisms of endocrine resistance in breast cancer, Annu. Rev. Med. 62 (2011) 233-247.

[137] Y. Rechoum, D. Rovito, D. Iacopetta, I. Barone, S. Andò, N.L. Weigel, et al., AR collaborates with ER $\alpha$ in aromatase inhibitor-resistant breast cancer, Breast Cancer Res. Treat. 147 (2014) 473-485.

[138] F.M. Blows, K.E. Driver, M.K. Schmidt, A. Broeks, F.E. van Leeuwen, J. Wesseling, et al., Subtyping of breast cancer by immunohistochemistry to investigate a relationship between subtype and short and long term survival: a collaborative analysis of data for 10,159 cases from 12 studies, PLoS Med. 7 (2010) e1000279.

[139] H. Mohammed, I.A. Russell, R. Stark, O.M. Rueda, T.E. Hickey, G.A. Tarulli, et al., Progesterone receptor modulates ER alpha action in breast cancer, Nature 523 (2015) 313-317.

[140] S. Karmakar, Y. Jin, A.K. Nagaich, Interaction of glucocorticoid receptor (GR) with estrogen receptor (ER) alpha and activator protein 1 (AP1) in dexamethasone-mediated interference of ERalpha activity, J. Biol. Chem. 288 (2013) 24020-24034.

[141] M. Kok, W. Zwart, C. Holm, R. Fles, M. Hauptmann, L.J. Van't Veer, et al., PKAinduced phosphorylation of ER alpha at serine 305 and high PAK1 levels is associated with sensitivity to tamoxifen in ER-positive breast cancer, Breast Cancer Res. Treat. 125 (2011) 1-12.

[142] I.J. De Vries-van Leeuwen, D. da Costa Pereira, K.D. Flach, S.R. Piersma, C. Haase, D. Bier, et al., Interaction of 14-3-3 proteins with the estrogen receptor alpha F domain provides a drug target interface, PNAS 110 (2013) 8894 8899.

[143] G.G. Kuiper, E. Enmark, M. Pelto-Huikko, S. Nilsson, J.A. Gustafsson, Cloning of a novel receptor expressed in rat prostate and ovary, Proc. Natl. Acad. Sci. U.S. A. 93 (1996) 5925-5930.

[144] B. Huang, Y. Omoto, H. Iwase, H. Yamashita, T. Toyama, R.C. Coombes, et al. Differential expression of estrogen receptor alpha, beta1, and beta2 in lobular and ductal breast cancer, Proc. Natl. Acad. Sci. U.S.A. 111 (2014) 1933-1938.

[145] C. Thomas, J.A. Gustafsson, The different roles of ER subtypes in cancer biology and therapy, Nat. Rev. Cancer 11 (2011) 597-608.

[146] S. Paruthiyil, H. Parmar, V. Kerekatte, G.R. Cunha, G.L. Firestone, D.C. Leitman, Estrogen receptor beta inhibits human breast cancer cell proliferation and tumor formation by causing a G2 cell cycle arrest, Cancer Res. 64 (2004) 423428.

[147] B. Yuan, L. Cheng, H.C. Chiang, X. Xu, Y. Han, H. Su, et al., A phosphotyrosine switch determines the antitumor activity of ER beta, J. Clin. Invest. 124 (2014) 3378-3390.

[148] L.J. Wang, S.X. Han, E. Bai, X. Zhou, M. Li, G.H. Jing, et al., Dose-dependent effect of tamoxifen in tamoxifen-resistant breast cancer cells via stimulation by the ERK1 / 2 and AKT signaling pathways, Oncol. Rep. 29 (2013) 15631569.

[149] J. Baselga, M. Campone, M. Piccart, H.A. Burris 3rd, H.S. Rugo, T. Sahmoud, et al., Everolimus in postmenopausal hormone-receptor-positive advanced breast cancer, NEJM 366 (2012) 520-529.

[150] L. Yu, W. Ke, Y. Wang, W. Ding, B. Wang, S. Huang, et al., Predictive and prognostic value of ER- $\alpha 36$ expression in breast cancer patients treated with chemotherapy, Steroids 84 (2014) 11-16.

[151] G. Li, J. Zhang, K. Jin, K. He, Y. Zheng, X. Xu, et al., Estrogen receptor- $\alpha 36$ is involved in development of acquired tamoxifen resistance via regulating the growth status switch in breast cancer cells, Mol. Oncol. 7 (2013) 611-624.

[152] L. Kang, X. Zhang, Y. Xie, Y. Tu, D. Wang, Z. Liu, et al., Involvement of estrogen receptor variant ER- $\alpha 36$, not GPR30, in nongenomic estrogen signaling, Mol. Endocrinol. 24 (2010) 709-721.

[153] V. Laudet, C. Hänni, J. Coll, F. Catzeflis, D. Stéhelin, Evolution of the nuclear receptor gene superfamily, EMBO J. 11 (1992) 1003-1013.

[154] M. Kammerer, S. Gutzwiller, D. Stauffer, I. Delhon, Y. Seltenmeyer, B. Fournier Estrogen Receptor alpha (ER alpha) and Estrogen Related Receptor alpha (ERR alpha) are both transcriptional regulators of the Runx2-I isoform, Mol. Cell. Endocrinol. 369 (2013) 150-160.

[155] G. Deblois, V. Giguere, Oestrogen-related receptors in breast cancer: control of cellular metabolism and beyond, Nat. Rev. Cancer 13 (2013) 27-36.

[156] Z. Xu, J. Liu, L. Gu, X. Ma, B. Huang, X. Pan, Research progress on the reproductive and non-reproductive endocrine tumors by estrogen-related receptors, J. Steroid Biochem. Mol. Biol. 158 (2016) 22-30.

[157] D. Sengupta, D. Bhargava, A. Dixit, B. Sahoo, S. Biswas, G. Biswas, et al., ERR signalling through FST and BCAS2 inhibits cellular proliferation in breast cancer cells, Br. J. Cancer 110 (2014) 2144-2158.

[158] N. Ijichi, T. Shigekawa, K. Ikeda, K. Horie-Inoue, T. Fujimura, H. Tsuda, et al., Estrogen-related receptor gamma modulates cell proliferation and estrogen signaling in breast cancer, J. Steroid Biochem. Mol. Biol. 123 (2011) 1-7.

[159] J. Ang, J. Sheng, K. Lai, S. Wei, X. Gao, Identification of estrogen receptorrelated receptor gamma as a direct transcriptional target of angiogenin, PLoS One 8 (2013), http://dx.doi.org/10.1371/journal.pone.0071487. e71487.

[160] B. Olde, L.M. Leeb-Lundberg, GPR30/GPER1: searching for a role in estrogen physiology, Trends Endocrinol. Metab. 20 (2009) 409-416.

[161] E.R. Prossnitz, J.B. Arterburn, International union of basic and clinical pharmacology. XCVII. G protein-coupled estrogen receptor and its pharmacologic modulators, Pharmacol. Rev. 67 (2015) 505-540.

[162] M. Pupo, A. Pisano, R. Lappano, M.F. Santolla, E.M. De Francesco, S. Abonante, et al., Bisphenol A induces gene expression change and proliferative effects trough GPER in breast cancer cells and cancer-associated fibroblasts, Environ. Health Perspect. 120 (2012) 1177-1182.

[163] H.A. Aiad, M.M. Wahed, N.Y. Asaad, M. El-Tahmody, E. Elhosary, Immunohistochemical expression of GPR30 in breast carcinoma of Egyptian patients: an association with immunohistochemical subtypes, APMIS 122 (2014) 976-984.

[164] T. Ignatov, C. Weißenborn, A. Poehlmann, A. Lemke, A. Semczuk, A. Roessner et al., GPER-1 expression decreases during breast cancer tumorigenesis, Cancer Invest. 31 (2013) 309-315. 
[165] M.F. Santolla, S. Avino, M. Pellegrino, E.M. DeFrancesco, P. DeMarco, R. Lappano, et al., SIRT1 is involved in oncogenic signaling mediated by GPER in breast cancer, Cell Death Dis. 6 (2015) e1834.

[166] Y. Li, L. Birnbaumer, C.T. Teng, Regulation of ERR $\alpha$ gene expression by estrogen receptor agonists and antagonists in SKBR3 breast cancer cells: differential molecular mechanisms mediated by G protein-coupled receptor GPR30/GPER-1, Mol. Endocrinol. 24 (2010) 969-980.

[167] X. Zhou, S. Wang, Z. Wang, X. Feng, P. Liu, X.B. Lv, et al., Estrogen regulates Hippo signaling via GPER in breast cancer, J. Clin. Invest. 125 (2015) 21232135.

[168] S. Catalano, C. Giordano, S. Panza, F. Chemi, D. Bonofiglio, M. Lanzino, et al., Tamoxifen through GPER up-regulates aromatase expression: a novel mechanism sustaining tamoxifen-resistant breast cancer cell growth, Breast Cancer Res. Treat. 146 (2014) 273-285.

[169] G. Mor, W. Yue, R.J. Santen, L. Gutierrez, M. Eliza, L.M. Berstein, et al., Macrophages, estrogen and the microenvironment of breast cancer, J. Steroid Biochem. Mol. Biol. 67 (1998) 403-411.

[170] R. Siegel, D. Naishadham, A. Jemal, Cancer statistics, CA Cancer J. Clin. 63 (2013) 11-30.

[171] J.V. Bokhman, Two pathogenetic types of endometrial carcinoma, Gynecol. Oncol. 15 (1983) 10-17.

[172] S.G. Silverberg, R.J. Kurman, F. Nogales, G.L. Mutter, R.A. Kubik-Huch, F.A. Tavassoli, Epithelial tumours and related lesions, in: F.A. Tavassoli, P. Devilee (Eds.), World Health Organization Classification of Tumours: Pathology and Genetics - Tumours of the Breast and Female Genital Organs, IARC Press, Lyon, 2003, pp. 217-232.

[173] R. Murali, R.A. Soslow, B. Weigelt, Classification of endometrial carcinoma: more than two types, Lancet Oncol. 15 (2014) e268-e278.

[174] K.J. Dedes, D. Wetterskog, A. Ashworth, S.B. Kaye, J.S. Reis-Filho, Emerging therapeutic targets in endometrial cancer, Nat. Rev. Clin. Oncol. 8 (2011) $261-271$.

[175] N.R. Abu-Rustum, Q. Zhou, J.D. Gomez, K.M. Alektiar, M.L. Hensley, R.A. Soslow, et al., A nomogram for predicting overall survival of women with endometrial cancer following primary therapy: toward improving individualized cancer care, Gynecol. Oncol. 116 (2010) 399-403.

[176] H.B. Salvesen, I.S. Haldorsen, J. Trovik, Markers for individualized therapy in endometrial carcinoma, Lancet Oncol. 13 (2012) 353-361.

[177] V.W. Setiawan, H.P. Yang, M.C. PikeAustralian National Endometrial Cancer Study Group, Type I and II endometrial cancers: have they different risk factors?, J Clin. Oncol. 31 (2013) 2607-2618.

[178] M. Muramatsu, S. Inoue, Estrogen receptors: how do they control reproductive and nonreproductive functions?, Biochem Biophys. Res. Commun. 270 (2000) 1-10.

[179] M.G. Rosenfeld, C.K. Glass, Coregulator codes of transcriptional regulation by nuclear receptors, J. Biol. Chem. 276 (2001) 36865-36868.

[180] M. Marino, P. Galluzzo, P. Ascenzi, Estrogen signaling multiple pathways to impact gene transcription, Curr. Genomics 7 (2006) 497-508.

[181] P. Ordonez-Moran, A. Munoz, Nuclear receptors: genomic and nongenomic effects converge, Cell Cycle 8 (2009) 1675-1680.

[182] Z. Wang, X. Zhang, P. Shen, B.W. Loggie, Y. Chang, T.F. Deuel, Identification, cloning, and expression of human estrogen receptor-alpha36, a novel variant of human estrogen receptor-alpha66, Biochem. Biophys. Res. Commun. 336 (2005) 1023-1027.

[183] Y. Zou, L. Ding, M. Coleman, Z. Wang, Estrogen receptor-alpha (ER-alpha) suppresses expression of its variant ER-alpha 36, FEBS Lett. 583 (2009) 13681374.

[184] J.S. Tong, Q.H. Zhang, Z.B. Wang, S. Li, C.R. Yang, X.Q. Fu, et al., ER- $\alpha 36$, a novel variant of ER- $\alpha$, mediates estrogen-stimulated proliferation of endometrial carcinoma cells via the PKC $/$ ERK pathway, PLoS One 5 (2010) e15408.

[185] Z. Wang, X. Zhang, P. Shen, B.W. Loggie, Y. Chang, T.F. Deuel, A variant of estrogen receptor-\{alpha\}, hER-\{alpha\}36: transduction of estrogen- and antiestrogen-dependent membrane-initiated mitogenic signaling, Proc. Natl. Acad. Sci. U.S.A. 103 (2006) 9063-9068.

[186] S.L. Lin, L.Y. Yan, X.W. Liang, Z.B. Wang, Z.Y. Wang, J. Qiao, et al., A novel variant of ER-alpha, ER-alpha36 mediates testosterone-stimulated ERK and Akt activation in endometrial cancer Hec1A cells, Reprod. Biol. Endocrinol. 7 (2009) 102.

[187] R.X. Guo, L.H. Wei, Z. Tu, P.M. Sun, J.L. Wang, D. Zhao, et al., 17 beta-estradiol activates PI3K/Akt signaling pathway by estrogen receptor (ER)-dependent and ER-independent mechanisms in endometrial cancer cells, J. Steroid Biochem. Mol. Biol. 99 (2006) 9-18.

[188] R.W. Muchekehu, B.J. Harvey, 17beta-estradiol rapidly mobilizes intracellular calcium from ryanodine-receptor-gated stores via a PKC-PKAErk- dependent pathway in the human eccrine sweat gland cell line NCL-SG3, Cell Calcium 44 (2008) 276-288.

[189] R.X. Song, R.A. McPherson, L. Adam, Y. Bao, M. Shupnik, R. Kumar, et al., Linkage of rapid estrogen action to MAPK activation by ERalpha-Shc association and Shc pathway activation, Mol. Endocrinol. 16 (2002) 116-127.

[190] D.W. Singleton, Y. Feng, C.J. Burd, S.A. Khan, Nongenomic activity and subsequent c-Fos induction by estrogen receptor ligands are not sufficient to promote deoxyribonucleic acid synthesis in human endometrial adenocarcinoma cells, Endocrinology 144 (2003) 121-128.

[191] Y. Ueda, S. Hirai, S. Osada, A. Suzuki, K. Mizuno, S. Ohno, Protein kinase C activates the MEK-ERK pathway in a manner independent of Ras and dependent on Raf, J. Biol. Chem. 271 (1996) 23512-23519.
[192] J.F. Liu, M. Crepin, J.M. Liu, D. Barritault, D. Ledoux, FGF-2 and TPA induce matrix metalloproteinase-9 secretion in MCF-7 cells through PKC activation of the Ras/ERK pathway, Biochem. Biophys. Res. Commun. 293 (2002) 11741182.

[193] V.C. Grossoni, K.B. Falbo, M.G. Kazanietz, E.D. de Kier Joffe, A.J. Urtreger, Protein kinase $\mathrm{C}$ delta enhances proliferation and survival of murine mammary cells, Mol. Carcinog. 46 (2007) 381-390.

[194] J. Koivunen, V. Aaltonen, J. Peltonen, Protein kinase C (PKC) family in cancer progression, Cancer Lett. 235 (2006) 1-10.

[195] P.G. Roy, A.M. Thompson, Cyclin D1 and breast cancer, Breast 15 (2006) 718 727.

[196] Q.J. Cao, M.H. Einstein, P.S. Anderson, C.D. Runowicz, R. Balan, J.G. Jones, Expression of COX-2, Ki-67, cyclin D1, and P21 in endometrial endometrioid carcinomas, Int. J. Gynecol. Pathol. 21 (2002) 147-154.

[197] H. Kashima, T. Shiozawa, T. Miyamoto, A. Suzuki, J. Uchikawa, M. Kurai, et al., Autocrine stimulation of IGF1 in estrogen-induced growth of endometrial carcinoma cells: involvement of the mitogen-activated protein kinase pathway followed by up-regulation of cyclin D1 and cyclin E, Endocr. Relat. Cancer 16 (2009) 113-122.

[198] H. Tong, J.Q. Ke, F.Z. Jiang, X.J. Wang, F.Y. Wang, Y.R. Li, et al., Tumorassociated macrophage-derived CXCL8 could induce ER $\alpha$ suppression via HOXB13 in endometrial cancer, Cancer Lett. 376 (2016) 127-136.

[199] X.F. Jiang, Q.L. Tang, H.G. Li, X.M. Shen, X. Luo, X.Y. Wang, et al., Tumorassociated macrophages correlate with progesterone receptor loss in endometrial endometrioid adenocarcinoma, J. Obstet. Gynaecol. Res. 39 (2013) 855-863.

[200] M.C. Pike, R.K. Peters, W. Cozen, N.M. Probst-Hensch, J.C. Felix, P.C. Wan, et al., Estrogen-progestin replacement therapy and endometrial cancer, J. Natl. Cancer Inst. 89 (1997) 1110-1116.

[201] B. Fisher, J.P. Costantino, C.K. Redmond, E.R. Fisher, D.L. Wickerham, W.M. Cronin, Endometrial cancer in tamoxifen-treated breast cancer patients: findings from the National Surgical Adjuvant Breast and Bowel Project (NSABP) B-14, J. Natl. Cancer Inst. Monogr. 86 (1994) 527-537.

[202] A.G. Renehan, M. Tyson, M. Egger, R.F. Heller, M. Zwahlen, Body-mass index and incidence of cancer: a systematic review and meta-analysis of prospective observational studies, Lancet 371 (2008) 569-578.

[203] P.T. Soliman, D. Wu, G. Tortolero-Luna, K.M. Schmeler, B.M. Slomovitz, M.S. Bray, et al., Association between adiponectin, insulin resistance, and endometrial cancer, Cancer 106 (2006) 2376-2381.

[204] D.G. Gallup, R.J. Stock, Adenocarcinoma of the endometrium in women 40 years of age or younger, Obstet. Gynecol. 64 (1984) 417-420.

[205] P.T. Soliman, J.C. Oh, K.M. Schmeler, C.C. Sun, B.M. Slomovitz, D.M. Gershenson, et al., Risk factors for young premenopausal women with endometrial cancer, Obstet. Gynecol. 105 (2005) 575-580.

[206] C.P. McPherson, T.A. Sellers, J.D. Potter, R.M. Bostick, A.R. Folsom, Reproductive factors and risk of endometrial cancer. The Iowa Women's Health Study, Am. J. Epidemiol. 143 (1996) 1195-1202.

[207] R.J. Zaino, W.E. Brady, W. Todd, K. Leslie, E.G. Fischer, N.S. Horowitz, Histologic effects of medroxyprogesterone acetate on endometrioid endometrial adenocarcinoma: a Gynecologic Oncology Group study, Int. J. Gynecol. Pathol. 33 (2014) 543-553.

[208] V. Bonadona, B. Bonaïti, S. Olschwang, S. Grandjouan, L. Huiart, M. Longy, et al., Cancer risks associated with germline mutations in MLH1, MSH2, and MSH6 genes in Lynch syndrome, JAMA 305 (2011) 2304-2310.

[209] X.P. Zhou, S. Kuismanen, M. Nystrom-Lahti, P. Peltomaki, C. Eng, Distinct PTEN mutational spectra in hereditary non-polyposis colon cancer syndrome-related endometrial carcinomas compared to sporadic microsatellite unstable tumors, Hum. Mol. Genet. 11 (2002) 445-450.

[210] C. Eng, PTEN: one gene, many syndromes, Hum. Mutat. 22 (2003) 183-198.

[211] D.A. Levine, O. Lin, R.R. Barakat, M.E. Robson, D. McDermott, L. Cohen, et al., Risk of endometrial carcinoma associated with BRCA mutation, Gynecol. Oncol. 80 (2001) 395-398.

[212] Y. Zhang, D. Zhao, C. Gong, F. Zhang, J. He, W. Zhang, et al., Prognostic role of hormone receptors in endometrial cancer: a systematic review and metaanalysis, World J. Surg. Oncol. 13 (2015) 208.

[213] M.J. Carlson, K.W. Thiel, K.K. Leslie, Past, present, and future of hormonal therapy in recurrent endometrial cancer, Int. J. Womens Health 6 (2014) 429-435.

[214] K.C. Podratz, P.C. O’Brien, G.D. Malkasian Jr., D.G. Decker, J.A. Jefferies, J.H. Edmonson, Effects of progestational agents in treatment of endometrial carcinoma, Obstet. Gynecol. 66 (1985) 106-110.

[215] J.D. Wright, N.I. Barrena Medel, J. Sehouli, K. Fujiwara, T.J. Herzog, Contemporary management of endometrial cancer, Lancet 379 (2012) 1352-1360.

[216] S.B. Decruze, J.A. Green, Hormone therapy in advanced and recurrent endometrial cancer: a systematic review, Int. J. Gynecol. Cancer 17 (2007) 964-978.

[217] T. Thigpen, M.F. Brady, H.D. Homesley, J.T. Soper, J. Bell, Tamoxifen in the treatment of advanced or recurrent endometrial carcinoma: a Gynecologic Oncology Group study, J. Clin. Oncol. 19 (2001) 364-367.

[218] B.B. Ma, A. Oza, E. Eisenhauer, G. Stanimir, M. Carey, W. Chapman, et al., The activity of letrozole in patients with advanced or recurrent endometrial cancer and correlation with biological markers study of the National Cancer Institute of Canada Clinical Trials Group, Int. J. Gynecol. Cancer 14 (2004) 650-658. 
[219] J.V. Fiorica, V.L. Brunetto, P. Hanjani, S.S. Lentz, R. Mannel, W. Andersen, Phase II trial of alternating courses of megestrol acetate and tamoxifen in advanced endometrial carcinoma: a Gynecologic Oncology Group study, Gynecol. Oncol. 92 (2004) 10-14.

[220] L.M. Ramondetta, A.J. Johnson, C.C. Sun, N. Atkinson, J.A. Smith, M.S. Jung Phase 2 trial of mifepristone (RU-486) in advanced or recurrent endometrioid adenocarcinoma or lowgrade endometrial stromal sarcoma, Cancer 115 (2009) 1867-1874.

[221] F. Kokka, E. Brockbank, D. Oram, C. Gallagher, A. Bryant, Hormonal therapy in advanced or recurrent endometrial cancer, Cochrane Database Syst. Rev. 12 (2010), http://dx.doi.org/10.1002/14651858.CD007926.pub2 CD007926.

[222] M. Friedlander, K.M. Sjoquist, D.W. Sommeijer, L. Bailey, J. Martyn, K. Gillies, PARAGON: phase II study of aromatase inhibitors in women with potentially hormone responsive recurrent/metastatic gynecologic neoplasms: ANZGOG 0903, J. Clin. Oncol. 31 (2013) (suppl; abstr TPS5614).
223] A.L. Covens, V. Filiaci, D. Gersell, C.V. Lutman, A. Bonebrake, Y.C. Lee, Phase II study of fulvestrant in recurrent/metastatic endometrial carcinoma: Gynecologic Oncology Group study, Gynecol. Oncol. 120 (2011) 185-188.

[224] G. Emons, A. Gunthert, F.C. Thiel, O. Camara, H.G. Strauss, G.P. Breitbach, Phase II study of fulvestrant $250 \mathrm{mg} /$ month in patients with recurrent or metastatic endometrial cancer: a study of the Arbeitsgemeinschaft Gynakologische Onkologie, Gynecol. Oncol. 129 (2013) 495-499.

[225] S. Lheureux, A.M. Oza, Endometrial cancer targeted therapies myth or reality? Review of current targeted treatments, Eur. J. Cancer 59 (2016) 99108.

[226] L.W. Woo, D. Ganeshapillai, M.P. Thomas, O.B. Sutcliffe, B. Malini, M.F. Mahon, et al., Structure-activity relationship for the first-in-class clinical steroid sulfatase inhibitor Irosustat (STX64, BN83495), ChemMedChem 6 (2011) 2019-2034.

[227] A. Purohit, L.W. Woo, B.V. Potter, Steroid sulfatase: a pivotal player in estrogen synthesis and metabolism, Mol. Cell. Endocrinol. 4 (2011) 154-160. 